\title{
Regulatory incentives and financial reporting quality in public healthcare organisations
}

Article

Accepted Version

Greenwood, M. J., Baylis, R. M. and Tao, L. (2017) Regulatory incentives and financial reporting quality in public healthcare organisations. Accounting and Business Research, 47 (7). pp. 831-855. ISSN 0001-4788 doi:

https://doi.org/10.1080/00014788.2017.1343116 Available at https://centaur.reading.ac.uk/88646/

It is advisable to refer to the publisher's version if you intend to cite from the work. See Guidance on citing.

To link to this article DOI: http://dx.doi.org/10.1080/00014788.2017.1343116

Publisher: Taylor \& Francis

All outputs in CentAUR are protected by Intellectual Property Rights law, including copyright law. Copyright and IPR is retained by the creators or other copyright holders. Terms and conditions for use of this material are defined in the End User Agreement.

www.reading.ac.uk/centaur 
Central Archive at the University of Reading

Reading's research outputs online 


\title{
Regulatory incentives and financial reporting quality in public healthcare organisations
}

\author{
MARGARET J. GREENWOOD ${ }^{\mathrm{a} *}$, RICHARD M. BAYLIS $^{\mathrm{b}}$ and LEI TAO ${ }^{\mathrm{c}}$ \\ A School of Management, University of Bath, Bath, UK; b Cardiff Business School, Cardiff \\ University, \\ Cardiff, UK; c Portsmouth Business School, University of Portsmouth, Portsmouth, UK
}

\begin{abstract}
English National Health Service Foundation Trusts are subject to a regulatory regime in which the level of monitoring and intervention is determined by performance against two key performance metrics: a 'financial risk rating', based on a number of performance metrics (such as the reported surplus and return on assets), and a 'prudential borrowing limit', a measure of borrowing capacity. In this paper we investigate the variation in financial reporting quality, proxied by discretionary accruals, with the incentives introduced by this regime. We find: first, that discretionary accruals are managed to report small surpluses; second, that, consistent with the avoidance of regulatory intervention in both the short and medium term, discretionary accruals are more positive/negative when pre-managed performance is below/well above intervention triggering thresholds; third, that, despite a move away from financial breakeven as the primary performance objective, there remains an aversion to small loss reporting. We further find that the level of discretionary accruals is driven by two metrics of strategic significance: the surplus margin (a measure of retained earnings) and the prudential borrowing limit, a measure of borrowing capacity.
\end{abstract}

Key words: discretionary accruals; healthcare; public sector; regulation. 


\section{Regulatory incentives and financial reporting quality in public healthcare organisations}

\section{Introduction}

Over the past thirty years an ongoing programme of public sector reform throughout the OECD has resulted in the increased marketization of public services, the corporatisation of public sector entities, and the emulation of private sector 'best practice' including increased managerial freedom (Pollitt and Bouckaert 2011). Such reforms are widely referred to as New Public Management (NPM) (Hood 1991, 1995) and have been particularly pronounced in the area of healthcare, where public spending accounts for more than 7\% of GDP for most of Europe, the British Commonwealth and the US ${ }^{1}$ (House of Commons 2011, p.4). To protect both public money and services there has been a corresponding growth in risk-based regulation in which the extent of scrutiny and intervention into public service providers has been determined by their performance against a number of pre-determined performance metrics and in which an assessment of financial sustainability plays a key role (Black and Baldwin 2010). In this context, variations in financial reporting quality could serve to undermine both regulatory effectiveness and resource allocation across and between public services. In this paper, we investigate the variation of financial reporting quality with regulatory incentives when public entities are granted considerable managerial freedom and are subject to a risk based regulatory regime.

Whilst agency theory predicts the management of financial performance to avoid regulatory intervention and to trigger rewards for good performance, theories of public service motivation offer an alternative framework in which we might not expect significant management of reported performance. First, the primary objective of public sector organisations is service delivery rather than the generation of profit (International Public Sector Accounting Standards Board® (IPSASB®) 2014, p.4). Second, the incentive framework in the public sector is weak: the incidence of performance related pay is low and has a focus on service delivery rather than financial performance (The Work Foundation 2014). Third, information asymmetry between organisational managers and those monitoring and evaluating their performance is often low:

\footnotetext{
${ }^{1}$ Total spending on healthcare in the US is more than twice that of other nations but approximately half is represented by public (federal) spending mainly on the Medicare and Medicaid programmes.
} 
regulators and funding providers often have the power and resources to demand additional information which reduces the potential for disguising underlying performance. These factors arguably combine to create a culture which is inimical to the misleading of key stakeholders, such as regulators and the public, about the underlying financial performance of the entity. However, NPM-inspired reforms have undoubtedly strengthened the incentive framework and in this context there has been some concern, and evidence, that such reforms erode and 'crowd out' public service motivation and values (Georgellis et al. 2011, Jørgensen and Anderson 2011, Bellé 2015). Further, with the widespread adoption of accruals accounting throughout the OECD public sector (Blöndal 2003), the incentives and opportunities for the management of reported financial performance have been increasing.

In not for profit entities, for example, Jegers (2010) has analysed the manipulation of earnings and other financial indicators and shows that agency problems exacerbate earnings management with a potentially negative impact on welfare, an issue also raised in a study of performance measurement practices in the public sector by Cuganesan et al. (2014). They identify the tensions between the performance of individual accounting entities and broader system objectives with, for example, '..an emphasis on local goal achievement at the expense of broader global objectives, and a focus on measured performance dimensions to the detriment of unmeasured ones such as system responsibility and important inter-organisational collaboration' (p.281). Both Jegers (2010) and Cuganesan et al. (2014) call for additional research into performance measurement in the public sector with a view to exploring the risks associated with current practice. This paper represents a response to these calls.

Our setting is English National Health Service Foundation Trusts. Foundation Trusts account for more than $£ 30 \mathrm{bn}$, (or roughly $30 \%$ ), of UK annual public expenditure on healthcare ${ }^{2}$. They were established from 2004-05 and have been granted an unprecedented level of managerial freedom (Lapsley and Schofield 2009) including the ability to retain surpluses and to borrow commercially in order to fund their strategic development, over which they exercise a high degree of autonomy. Foundation Trusts are subject to regulation by an independent regulator, Monitor, (Health and Social Care

http://webarchive.nationalarchives.gov.uk/20140131031506/http:/www.archive.officialdocuments.co.uk/document/parlment/nolan/nolan.htm (accessed 27 November 2015) 
(Community Health and Standards) Act 2003) which operates a risk-based regulatory regime $^{3}$ (Monitor 2009b p.5). Poor performance against a number of financial metrics results in intervention in the form of additional monitoring and possible replacement of the Board and Governing Body (Health and Social Care (Community Health and Standards) Act 2003, s.23, National Health Service Act 2006, s.52) whilst good performance results in a reduction in the intensity of monitoring, and access to additional sources of funding. Regulatory action is triggered by performance against two key metrics: a 'financial risk-rating' ${ }^{4}$, which aims to measure financial sustainability, and which is an aggregate measure of performance (comprising EBITDA margin, surplus margin, return on assets, liquidity and performance against plan) and a 'prudential borrowing limit' which is a measure of gearing and borrowing capacity. This regime thus introduces incentives for the avoidance of regulatory intervention and for the triggering of additional managerial autonomy.

Prior literature has explored accruals management in public sector entities only in response to the financial breakeven benchmark and has found income increasing (decreasing) discretionary accruals when pre-managed performance is below (above) this benchmark and that public entities also manage discretionary accruals to avoid the reporting of small losses (Leone and Van Horn 2005, Ballantine et al. 2007). We contribute to this literature and to our understanding of financial reporting quality in the public sector by investigating the impact of a new form of public sector regulation. We use discretionary accruals as our proxy for financial reporting quality and, using data sourced from financial statements and the regulator's reporting template, estimate a pre-managed risk rating and prudential borrowing limit. We find that: first, discretionary accruals are income increasing (decreasing) for pre-managed deficits (surpluses) indicating that financial performance is managed to report small surpluses;

${ }^{3}$ A risk based regulatory regime is one in which the level of monitoring and of regulatory intervention is proportionate to the assessed risk to services and/or financial sustainability. Such regimes are being increasingly adopted as public money is increasingly devolved to service providers with increasing levels of managerial freedom, and in order to generate efficiency in regulatory costs by targeting regulatory attention where it is most needed. For a summary of the key features of a risk based regulatory regime, see Black and Baldwin 2010, pp. 183-185. The Foundation Trust regulatory regime exhibits these key features.

4 'Financial risk rating' is the regulator's terminology and includes metrics which are related to operational performance (such as EBITDA and \% of plan EBITDA achieved) as well as metrics related for example to liquidity. The term is used to distinguish it from service based non-financial metrics such as waiting times for treatment. 
second, consistent with incentives to avoid regulatory intervention, discretionary accruals are significantly more positive when the pre-managed risk rating is just below the intervention triggering threshold and when the prudential borrowing limit is breached; third, consistent with incentives to protect future performance against cost and revenue pressures, and the possibility of future regulatory intervention, that they are significantly more negative when well above the risk ratings intervention threshold; fourth, that, despite a move away from financial breakeven as a key objective, there remains an aversion to small loss reporting. When the financial risk rating is disaggregated we further find that the management of discretionary accruals is being driven by the income and expenditure surplus (deficit), a measure of retained earnings and a key performance metric for all stakeholders, and by the prudential borrowing limit, a breach of which would have implications for the strategic capacity of the Trust.

This paper proceeds as follows: section 2 considers prior literature; section 3 gives further contextual information regarding the institutional setting; section 4 sets out our method, data and sampling; section 5 reports our findings and section 6 concludes with a discussion and consideration of the implications of our findings.

\section{Prior literature}

Prior empirical studies in the not-for-profit and public sectors have focused on reported surpluses and show that, in response to the need to protect existing and future levels of funding and for the signalling of competence in the use of resources, entities manage earnings to report small surpluses close to zero demonstrating an aversion not only to the reporting of losses (consistent with the findings of the much more substantive private sector literature), but also to the reporting of large surpluses. Evidence of such management has been found in both public and not-for-profit hospitals (Hoerger 1991, Leone and Van Horn 2005, Ballantine et al. 2007) and in the not-for-profit sector more generally (Verbruggen and Christiaens 2012).

Ballantine et al. (2008) in the UK, and Eldenburg et al. (2004) in the US also provide evidence of incentives to avoid the reporting of losses by finding that board turnover is higher when losses are reported. Consistent with a profit objective, such turnover was found to be higher in for-profit hospitals than not-for-profit hospitals (Eldenburg et al. 2004). Hoerger (1991) similarly finds that the variability of profitability is greater in for-profit than not-for-profit hospitals. In the not-for-profit 
sector in the US, the manipulation of accounting numbers has also been found in the form of cost-shifting in response to managerial compensation incentives (Krishnan et al. 2006, Jones and Roberts 2006) and in order to reduce reported administrative and fund-raising expenditure for the purposes of enhancing the perceived efficiency of the entity by donors (Krishnan and Yetman 2011).

Prior research in the private sector indicates that the regulatory setting, and the possibility of increased regulatory scrutiny in particular, creates incentives for the management of reported financial performance (Jones 1991, Mensah et al. 1994, Burgstahler and Dichev 1997, Kasznik 1999, Navissi 1999). There are currently no equivalent studies in the public sector environment. Public sector entities have conventionally been subject to a direct performance management regime, associated with a command and control culture, rather than the independent regulation which is associated with higher levels of managerial freedom. The institutional setting of Foundation Trusts, which is characterised by strong regulatory oversight offers an opportunity to address this gap.

A number of studies investigating accruals management in the public and notfor-profit sectors adopt the model developed by Leone and Van Horn (2005). They found a negative association between discretionary accruals and pre-managed performance and that discretionary accruals were managed to reduce both surpluses and deficits by about $44 \%$. Elsewhere, in Portuguese municipalities and in the wider notfor-profit sector, the reduction is found to be between $40 \%$ and $80 \%$ (Ferreira et al. 2013, Verbruggen and Christiaens 2012). However in a study of UK universities, Greenwood and Tao (2016) find that financial reporting quality improves with the extent of regulatory monitoring, as proxied by the proportion of public funds sourced from the sector regulator. This effect has also been observed in the US healthcare sector where Krishnan and Yetman (2011), in a study of not-for-profit hospitals, find that cost-shifting aimed at enhancing efficiency ratios is reduced with the proportion of funding sourced from the Medicare and Medicaid programmes. We contribute to this literature by investigating the extent of accruals management in a healthcare setting which is funded, almost entirely, by regulated public funding.

In the UK, Ballantine et al. (2007) have investigated accruals management in the public sector setting of English National Health Service (NHS) Trusts, the 
predecessors of NHS Foundation Trusts. NHS Trusts were subject to direct performance management by the Department of Health and the primary financial objective was a statutorily enshrined annual performance target of financial breakeven (National Health Service and Community Care Act 1990). In this institutional setting the use of discretionary accruals to report small surpluses just above zero was found to be particularly marked. However, with the establishment, from 2004-05, of Foundation Trusts, the emphasis moved away from a primary focus on financial breakeven to performance evaluation based on multiple financial metrics and the generation of surpluses to fund service development. We contribute to the literature by investigating the impact of this new regulatory regime on financial reporting quality.

\section{Regulatory setting and hypothesis development}

NHS Foundation Trusts were established from 2004-05 as the preferred model of healthcare service delivery in England (Health and Social Care (Community Health and Standards) Act 2003). As at the end of 2013-14 there were 147 Foundation Trusts in total, represented by 101 trusts delivering acute hospital services and 46 delivering mental health or ambulance services. They receive most of their capital, in the form of 'taxpayers' equity', and revenues, in the form of contracted payments for patient treatments, from other public bodies but are free from central government control. Instead, they report directly to Parliament and are subject to regulation by an independent regulator, Monitor. A distinctive feature of the setting is that, unlike their predecessor organisations (NHS Trusts) and other public sector entities, they are expected to generate surpluses for reinvestment into the strategic development of their services, over which they exercise a large degree of autonomy. A further radical innovation in the context of Foundation Trusts is their ability to borrow money from commercial markets to further fund their development.

Monitor adopts a risk based approach to regulation: the level of scrutiny and of intervention is determined by a financial risk rating ${ }^{5}$ and a prudential borrowing limit whose aim is to protect continuity of service by acting as a measure of financial viability (Monitor 2013).

\footnotetext{
5 'Financial risk rating' is the regulator's terminology to distinguish it from service based non-financial metrics such as waiting times for treatment. However the 'financial risk rating' includes metrics which are related to operational performance (such as EBITDA and \% of plan EBITDA achieved) as well as metrics related for example to liquidity.
} 
The financial risk rating is determined by performance against 5 component metrics. Figure 1 shows that these are categorised as being related to financial efficiency (measured by the I\&E surplus margin and return on assets - total weighting $40 \%$ ); underlying performance, (measured by the EBITDA margin \% - weighting 25 $\%$ ); liquidity (weighting 25\%) and plan performance (measured by EBITDA as a \% of plan - weighting 10\%).

Insert Figure 1 about here

A component risk rating of between 1 (poor) and 5 (good) is first determined by the threshold levels of performance in Figure 1. Appropriate weightings are then applied to these component risk ratings to arrive at a final overall risk rating of between 1 and 5. Risk ratings below 3 result in additional monitoring and other forms of intervention whilst risk ratings of 4 and above trigger less frequent monitoring, from quarterly to bi-annually, and the potential for greater managerial autonomy. An example illustrating how the final rating is calculated is included in Figure 1. This shows that a Trust with an I\&E surplus margin of $0.8 \%$ (component rating 2 ), an ROA of $3.5 \%$ (component rating 3), EBITDA margin of $6.2 \%$ (component rating 3), liquidity of 28 days (component rating 4) and a plan performance of $83 \%$ (component rating 3 ), achieves an overall financial risk rating of 3. This Trust's performance is therefore above the threshold for intervention even though the I\&E surplus component falls below a 3 rating.

The risk rating system also has features which discourage year-end accruals management: it is multi-dimensional such that the impact of manipulation is rendered less readily computable; the flattery of current year financial performance at the expense of future reported performance is mitigated by the capping of ratings for Trusts forecasting losses (Monitor 2009b, p.15); and finally, over-optimism in forecasting is discouraged through the $\%$ of plan performance metric (see Figure 1). However, notwithstanding these features, the framework creates incentives to manage performance in order to first, avoid intervention in the event of poor performance and second, to trigger rewards for better performance. This latter incentive is, however, tempered by incentives to manage performance downwards in order to signal efficiency 
and effectiveness in the use of resources; to avoid the adverse publicity associated with the reporting of high surpluses; and, in a period of pressures on public spending and year-on-year requirements to deliver efficiency savings, a desire to provide a contingency against future cost and revenue pressures. In this context accruals management has been a matter of concern to the regulator because when the health service is under financial pressure there is a heightened imperative to demonstrate efficiency and effectiveness in the use of public funds, not only in individual trusts but across the whole healthcare system. ${ }^{6}$

The second key metric which can determine regulatory intervention is the 'Prudential Borrowing Limit'. The ability to borrow funds from commercial sources is an NPM-inspired innovation which has the objective of delivering greater flexibility and managerial autonomy to Foundation Trusts in order to develop their services. However, to protect services from risky borrowing, this facility is regulated by the Prudential Borrowing Code (Health and Social Care (Community Health and Standards) Act 2003, s.12, Monitor 2009a). Based on experience in the US where notfor-profit hospitals with credit ratings equivalent to the minimum investment grade of BBB (Standard and Poor's, Fitch) have access to a wider range of affordable funding, the Prudential Borrowing Code requires that Foundation Trusts maintain a level of liquidity which is consistent with a BBB credit rating. This is determined by reference to four key ratios, based on annual plan projections, for which minimum levels of performance are required. The ratios are dividend ${ }^{7}$ cover, interest cover, debt service cover and debt service as a $\%$ of revenue. The minimum levels of performance can be seen in Figure 2. Breach of any one of these thresholds, either on actual or revised forecast performance, has the potential to trigger regulatory intervention and a reduction in borrowing capacity, thereby creating an incentive to manage performance to avoid breach of the prudential borrowing limit.

Insert Figure 2 about here

\footnotetext{
${ }^{6}$ This insight was obtained during an interview with a Monitor representative.

${ }^{7}$ The taxpayers' equity which funds Foundation Trusts is provided subject to the requirement to pay an annual 'public' dividend currently set at $3.5 \%$.
} 


\subsection{Hypothesis development}

Public motivation theory and the presence of a strong monitoring framework which incorporates features which discourage the management of accruals leads to our null hypothesis:

Hypothesis: There is no variation in discretionary accruals with pre-managed financial performance.

However, the regulatory environment of Foundation Trusts introduces incentives for the management of accruals and we therefore supplement this null hypothesis with alternative hypotheses.

Prior research in the public and not-for-profit sectors has found a negative association between discretionary accruals and pre-managed surpluses (Leone and Van Horn 2005, Ferreira et al. 2005, Verbruggen and Christiaens 2012) in response to incentives to signal efficiency and effectiveness in the use of resources, avoidance of the adverse consequences of reporting a deficit and weak incentives for reporting large surpluses. Ballantine et al also find accruals management in response to incentives to provide contingencies against future reductions in income and/or rises in costs. Similar incentives for managing accruals to report small surpluses exist in the Foundation Trust regime and we therefore expect discretionary accruals to be performance increasing in the presence of a pre-discretionary deficit and performance decreasing in the presence of a pre-discretionary surplus.

H1: There will be a negative association between discretionary accruals and the pre-managed surplus.

However, the Foundation Trust regulatory regime introduces new incentives for managing accruals so we test the general alternative hypothesis:

H2: Discretionary accruals are additionally managed in response to specific incentives introduced by the regulatory regime

The strongest incentive is that of intervention avoidance:

H2a: Discretionary accruals are additionally performance increasing to avoid intervention, i.e. when the pre-managed risk rating is 2 or when the premanaged prudential borrowing limit is breached. 
For each of the other pre-managed risk ratings, the incentives for accruals management over and above that captured by $\mathrm{H} 1$ are less clear. At levels of performance which are well above the threshold for intervention (pre-managed risk ratings of 4 or 5) the incentives to reduce reported performance are captured by the premanaged surplus in $\mathrm{H} 1$ and it is questionable as to whether the incentives to create contingencies against future cost and revenue pressures and to maintain a reputation for sustained good performance, which are not specific to the Foundation Trust setting, would result in accruals management greater than this. For those Trusts with a premanaged risk rating of 3 , rewards in the form of lower monitoring levels provide an incentive to manage performance upwards to gain a risk rating of 4 but this is moderated by the incentives to sustain performance over the medium term and to avoid future intervention. A Trust is unlikely to manage performance upwards this year if that puts at risk the ability to achieve a 3 rating in future years. On the other hand, at low levels of performance (pre-managed risk rating of 1) there may be issues of managerial competence with little scope of avoiding intervention. There may also be, for some Trusts, the possibility of 'big bath' accounting in order to flatter future reported performance and risk ratings.

Thus, in all the above circumstances, the alternative hypothesis is ambivalent about the level of additional accruals management:

H2b: For a pre-managed risk rating of 1, 3, 4 or 5 the level of accruals management is consistent with H1, i.e. no additional management

Finally, despite the move away from financial breakeven as the primary performance benchmark, loss aversion remains as a feature of the regulatory regime and both private sector and public sector literature finds that small loss avoidance is a strong motivator for accruals management.

H2c: Discretionary accruals will be more positive for small premanaged deficits

To test these hypotheses we estimate discretionary accruals and investigate whether there is any variation with the pre-managed risk rating and with the prudential borrowing limit. 


\section{Research design}

\subsection{Sample and data}

Our sample includes all Foundation Trusts over the five year period from 200910 to 2013-14. The number of Trusts increases from 129 in 2009-10 to 147 in 2013-14 giving a total of 700 Trust observations. However, as a result of the deduction of partyear observations for Trusts which come into existence part way through the financial year, the absence of lagged observations for new Trusts, and the requirement for leading and lagging data in the modelling of discretionary accruals our sample reduces to 518 observations representing the four years from 2009-10 to 2012-13. The final sample for our multivariate analysis is further reduced to 332 observations as a consequence of the requirement for lagged data and 41 missing data for Trusts working capital facility. ${ }^{8}$

Financial statement data for the years 2009-10 and 2010-11, and lagged variables for 2008-09, were obtained from the Laing and Buisson database of NHS financial statements. Data for 2011-12 to 2013-14 data was accessed direct from the Monitor consolidation schedules as was data for the working capital facility throughout the period of our study. ${ }^{9}$ Plan data was not available and is therefore omitted from our analysis.

\subsection{Accruals modelling}

In this paper, we adopt an aggregate accruals method. Although both aggregate accruals and the specific accrual of depreciation have been investigated in prior literature, no management of depreciation has been found (Stalebrink 2007, Pilcher and Van der Zahn 2010) and, in the Foundation Trust context both bad debts and inventory, which have been investigated elsewhere (Marquardt and Wiedman 2004), are low. In contrast there is flexibility in payables. Accrued expenses, for example, comprise many small items and have been rising over the period of our study. ${ }^{10}$ There also exists the

\footnotetext{
${ }^{8}$ This data is required for a calculation of the liquidity metric - see Figure 1.

${ }^{9}$ Monitor consolidation schedules were accessed via: https://www.gov.uk/government/collections/foundation-trust-consolidation-ftc-accounts-data. The publication of these schedules represents a recent innovation by Monitor in response to this study.. Monitor has confirmed that the data in the 2009-10 and 2010-11 data in the Laing and Buisson database has been taken from their consolidation schedules and the two sources are therefore identical.

${ }^{10}$ The mean value of payables over the period of our study has risen from $11 \%$ of assets ( $\left.£ 19 \mathrm{~m}\right)$ in 2010 to $14 \%(£ 30 \mathrm{~m})$ in 2014 . Over the same period cash has risen $13 \%$ of assets ( $£ 22 \mathrm{~m}$ ) in 2010 to $17.5 \%$ in 2013 , falling slightly to $15 \%(£ 29 \mathrm{~m})$ in 2014 . This has been a particular concern of the regulator because cash has also been rising and this raises questions about allocative efficiency, overall system
} 
possibility of exploiting long term provisions as a means of managing performance. For well-performing Trusts this is particularly beneficial because a long term provision can be increased and reduce the operating and surplus margins without adversely influencing the liquidity position. We therefore incorporate variations in our definition of the accruals that we investigate to capture both long term provisions and depreciation.

The basis for our modelling of accruals is the model of Dechow and Dichev (2002) which is based on cash flows. We adapt this model as recommended by McNichols (2002), and applied by Ballantine et al. (2007), to accommodate changes in revenue and the level of PPE (Equation 1). Using a pooled OLS regression, we estimate discretionary accruals as follows:

$$
\Delta W C_{i t}=\alpha_{1}+\alpha_{2} C F O_{i t-1}+\alpha_{3} C F O_{i t}+\alpha_{4} C F O_{i t+1}+\alpha_{5} \Delta R E V_{i t}+\alpha_{6} P P E_{i t}+\varepsilon_{i t}
$$

Where: $\quad W C_{i t}$ is calculated as the change in non-cash current assets from time $\mathrm{t}-1$ to time $\mathrm{t}$, minus the change in cash and minus the change in current liabilities for entity i; $C F O_{i t ~}, C F O_{i t}$ and $C F O_{i t+1}$ represent lagged, contemporaneous and leading cash flows from operations; $R E V_{i t}$ is the change in revenue from time $t-1$ to time $t$; $P P E_{i t}$ is property, plant and equipment at time $t ;{ }_{i t}$ is the residual, a measure of discretionary accruals. All variables are scaled by lagged total assets (Ballantine et al. 2007,). Further, to reflect the specific accounting and regulatory environment of Foundation Trusts and the potential use of long term accruals to manage reported financial performance, we also use alternative definitions of working capital to include depreciation and the change in long term provisions. The results of these estimations show that the inclusion of depreciation and long term provisions in our definition of working capital generates the highest explanatory power and we therefore adopt this definition for the purposes of our second stage analysis.

wide performance and the potential for public and political pressure for cash balances to be reduced in favour of improved services. 


\subsection{Model development}

To investigate the extent to which discretionary accruals vary in response to regulatory incentives we follow Leone \& Van Horne's (2005) model which tests for variation of discretionary accruals in a not-for-profit setting. They model discretionary accruals as a function of pre-managed performance, of last year's reported performance and last year's discretionary accruals.

To test our hypotheses we adapt this model by introducing an indicator variable which represents the pre-managed risk rating. We also include control variables for trust type, location and size, and year dummies to accommodate yearly variations for example in funding and in demand. We estimate the following regression:

$$
D A_{i t}=\alpha_{0}+\alpha_{1} \text { Pre-mSurp }_{i t}+\alpha_{2} \text { Rating }_{i t}+\alpha_{3} \text { RepSurp }_{i t-1}+\alpha_{4} D_{i t-1}+\alpha_{5} \text { Region } \alpha_{6} \text { Type }+\alpha_{7} T I_{i t-1}+\sum_{j=1}^{j=3} \alpha_{7+j} Y E A R_{j}+\varepsilon_{i t}
$$

Where: $D A$ is discretionary accruals from the estimation model, equation [1]; Pre-mSurp represents the pre-managed surplus scaled by lagged total assets; Rating is the pre-managed risk rating taking the values of $1,2,3$ or 4 (where 4 captures a risk rating of both 4 and 5); RepSurp is reported surplus scaled by lagged total assets.

This model allows for performance matching through the continuous variable $\operatorname{RepSurp}_{i t-1}$ (Kothari et al. 2005) and for the reversing out of discretionary accruals through the lagged variable $D A_{i t-1}{ }^{11}$. Region and Type are control variables representing location and Trust type based on the regulator's classifications of acute, acute specialist, acute teaching, mental health and ambulance; $T I_{i t-1}$ is lagged total income, a control variable for Trust size; YEAR is an indicator variable for the years 2010-11 to 20122013; $\varepsilon$ is the error term. Control variables are included to control for the possibility that local health economy factors, organisational size and organisational complexity or business model affect the level of discretionary accruals.

To calculate the pre-managed 'financial risk rating' we first compute the four pre-managed component ratings of I\&E surplus margin, EBITDA margin, ROA and liquidity metric using Monitor's reporting template ${ }^{12}$ for each year of our study. Thus

\footnotetext{
${ }^{11}$ Dechow et al. (2012) use a binary variable to allow for the reversing out of accruals. In this method we use, consistent with Leone and Van Horn (2005), a continuous variable to control for the potential autocorrelation in discretionary accruals.

${ }^{12} \mathrm{We}$ are grateful to Monitor for access to these templates.
} 
any minor changes in the metrics over the period, as shown in Figure 3, have been incorporated into our estimates. For the I\&E surplus margin, the EBITDA margin and the ROA metrics, discretionary accruals are deducted from the reported EBITDA and I\&E surplus figures and from the assets/capital employed figure; for the liquidity metric discretionary accruals are deducted from the reported 'net liquid resources' ${ }^{13}$ and operating expenses. A pre-managed aggregate rating is then computed on the basis of these four metrics ${ }^{14}$. Data for the 'performance against plan' metric, which represents $10 \%$ of the final risk rating was not accessible and therefore was omitted from our calculation. We discuss the implications of this for the interpretation of our findings in Section 5.3.

Insert Figure 3 about here

We further investigate the influence on financial reporting quality of a premanaged breach of the prudential borrowing limit and, in order to gain some insight into the management of individual component metrics of the risk rating, a pre-managed component rating of 2 (signalling the risk of intervention) for each of the EBITDA\%, surplus $\%$, ROA $\%$ and liquidity metrics.

$D_{i t}=\alpha_{0}+\alpha_{1}$ Pre-mSurp $_{i t}+\alpha_{2}$ Comp $_{i t}+\alpha_{3}$ RepSurp $_{i t-1}+\alpha_{4} D_{i t-1}+\alpha_{5}$ Region $\alpha_{6}$ Type $+\alpha_{7} T I_{i t-1}+\sum_{j=1}^{j=3} \alpha_{7+j} Y E A R_{j}+\varepsilon_{i t} \quad[3]$

Where: Comp is an indicator variable which takes the value of 1 when the premanaged prudential borrowing limit is breached or when an individual component of the risk rating (EBITDA\%, surplus \%, ROA\% and liquidity) is 2 . To compute the premanaged prudential borrowing metric we deduct discretionary accruals from the reported 'revenue available for debt service' (see Figure 2).

13 Net liquid resources are defined as: Current Assets (excl. Inventories, Derivative Related Assets, Available/Held for Sale Assets and Charitable Funds Assets) - Current Liabilities (excl. Charitable Funds Liabilities) + any unused 'Committed Working Capital Facilities'. Foundation Trusts are required by the regulator to have working capital facilities in place with banks amounting to about one month's operational expenditure. (See Figure 3).

${ }^{14}$ The weightings of $20 \%, 20 \%, 25 \%$ and $25 \%$ are applied (as per Figure 1 ) to each of the I\&E surplus margin, the ROA metrics, the EBITDA margin and the liquidity metric respectively. The sum of these weighted ranking (which excludes the 'performance against plan' metric (weighting 10\%) is then grossed up (divided by 0.9) to arrive at the equivalent 'financial risk rating'. 
However, whilst we predict accruals management in response to a potential breach of the prudential borrowing limit (Hypothesis 2a) it is not possible to make the same prediction about individual component metrics. As illustrated in Figure 2 a rating of 2 on one metric may be offset by performance on one or more other metrics, resulting in a 3 (or greater) rating overall. Nonetheless this part of our analysis will provide some insights into the underlying dynamics of accruals management in this setting.

Our predictions for the expected signs on each of the independent variables can be found in Figure 4.

Insert Figure 4 about here

The coefficient $\alpha_{1}$ on Pre-mSurp in equations 2 and 3 tests Hypothesis 1 and we expect this coefficient to take a negative value to indicate income increasing (decreasing) discretionary accruals for pre-managed deficits(surpluses). The coefficient $\alpha_{2}$ on Rating in equation 2 and on Comp in equation 3 tests hypothesis $2 \mathrm{a}$. We expect this coefficient to be positive when the pre-managed risk rating is 2 and when the premanaged prudential borrowing limit is breached, indicating additional accruals management to avoid regulatory intervention. Finally, the coefficient $\alpha_{2}$ on Comp in equation 3 also tests Hypothesis 2b. We expect $\alpha_{2}$ to be positive for a small premanaged deficit indicating additional accruals management in order to avoid reporting a small loss. We predict no additional accruals management when the pre-managed risk rating is $1,3,4$ or 5 .

\section{Findings}

\subsection{Descriptive statistics and univariate analysis}

Descriptive statistics for our sample which set the context for our investigations are shown in Table 1.

Insert Table 1 about here 
Table 1 shows that the mean total income of our sample is $£ 267 \mathrm{~m}$ and mean total assets $£ 202 \mathrm{~m}$. Mean EBITDA and I\&E surplus as a \% of income amount to $6.1 \%$ and $1.6 \%$ respectively. Median values are similar at $6.0 \%$ and $1.4 \%$ respectively. Thus both mean and median values are above the thresholds (I\&E 1\% and EBITDA 5\%) for a component risk rating of 3 . The I\&E surplus margin in comparison with the EBITDA margin is more dispersed, less negatively skewed (-0.5 vs -1.0$)$ and more leptokurtic (kurtosis $=19.7$ vs 8.6 ). The closer proximity of the mean I\&E performance (1.6\%) to the threshold (1\%) and its higher dispersion (3.5\%) suggest that the I\&E margin may be more of a binding constraint than the EBITDA margin which at a mean value of $6.1 \%$ and lower dispersion (2.9\%) suggests more flexibility in achievement. In the full sample of 518 observations, a count of those achieving the EBITDA and I\&E margins associated with a component rating of 3 , reveals that 343 observations achieve the I\&E surplus target of $1 \%$ whereas 405 achieve the comparable EBITDA target of 5\%. With regard to liquidity the mean value of 29 days is well above the threshold (15 days) for a component risk rating of 3 but has large variability ( The mean value of the ROA of $3.4 \%$ is close to the threshold for a 3 rating (3\%) reflecting the similarity of the surplus measure with that used for the I\&E surplus margin. The high standard deviation (6.4) reflects the high variability in the asset base. The remaining rows of Table 1 set the context in which we investigate the potential for accruals management. In comparison with the mean I\&E surplus of $£ 4.3 \mathrm{~m}$, the mean value of net current assets (including cash) is $£ 11.2 \mathrm{~m}$. The mean value of payables is $£ 25 \mathrm{~m}$ representing almost $10 \%$ of total income. The mean value of depreciation, which does not affect the EBITDA margin but does have the potential for contributing to the management of the I\&E surplus and the ROA metrics, is $£ 7.4 \mathrm{~m}$. The mean bad debt expense is low at $£ 0.3 \mathrm{~m}$ but again with wide variability ( $\min £-4.4 \mathrm{~m}, \max £ 9.6 \mathrm{~m}$ ). Long term provisions amount to $£ 1.8 \mathrm{~m}$ (mean). Other figures in Table 1 illustrate that elsewhere there may limited scope for managing discretionary accruals: inventory is low with a mean value of $£ 3 \mathrm{~m}$ as are receivables which, with a mean value of $£ 11.4 \mathrm{~m}$, represent just 16 days of revenue, and which are represented largely (over $80 \%$ ) by NHS balances ${ }^{15}$.

We proceed to report in Table 2 the pairwise correlations for the component risk ratings and the prudential borrowing limit indicator. The components of the financial

\footnotetext{
${ }^{15}$ Non NHS receivables (not tabulated) have a mean value of about $£ 1 \mathrm{~m}$.
} 
risk rating are likely to be highly correlated as an improvement (worsening) in one metric such as EBITDA will be accompanied by an improvement in all the other risk rating components. As expected Table 2 shows the expected high levels of correlation for each variable, with the possible exception of the liquidity rating. As a consequence, in our multivariate analysis, we first apply Equation 3 to each component metric before including all four metrics in the one regression

Insert Table 2 about here

Then, as a first stage of our investigation of accruals management in response to regulatory incentives, Table 3 presents discretionary accruals analysed by the premanaged risk rating. This shows that discretionary accruals for a pre-managed risk rating of 2 are performance increasing to the extent of $1.1 \%$ of lagged total assets ( $\mathrm{p}=0.000$ ) or about $£ 2.2 \mathrm{~m}$ for a Trust with mean assets. For a Trust with a risk rating of 4 or 5 discretionary accruals are income decreasing to the extent of $1.6 \%$ of lagged total assets $(\mathrm{p}=0.002)$ or about $£ 3.2 \mathrm{~m}$ for a Trust with mean assets. The discretionary accruals for observations where the pre-managed risk rating is very poor (1) or just above the threshold for intervention (3) are not significantly different from zero. These findings provide prima facie evidence that the null hypothesis of no variation in discretionary accruals with underlying performance can be rejected.

Insert Table 3 about here

\subsection{Multivariate analysis}

Table 4 shows the results of Equation 2. Columns 1-4 show the results for each rating of 1,2, 3 and 4 or more (respectively) and Column 5 shows the results for a regression which includes all ratings, using a rating of 3 as the baseline group. The coefficient on the pre-managed surplus (Pre-mSurp) is negative and significant in all cases at $1 \%$. We can therefore reject the null hypothesis of no variation in discretionary accruals with underlying performance. The coefficient (in the order of -0.1) indicates that approximately $10 \%$ of the pre-managed surplus is reversed out through the use of discretionary accruals. This is lower than in prior studies and is consistent with 
Hypothesis 1. The results further show that, consistent with Hypothesis 2, discretionary accruals additionally vary with the pre-managed financial risk rating. Consistent with Hypothesis 2a, when the pre-managed rating is 2 (Column 2), discretionary accruals are found to be more positive (coefficient $0.011, \mathrm{p}<0.01$ ) and therefore performance enhancing. Consistent with Hypothesis $2 b$, there is no evidence of additional accruals management for a pre-managed rating of 1 or 3 . However, for a pre-managed risk rating of 4 or 5 above, and contrary to Hypothesis $2 b$, discretionary accruals are found to be more negative (coefficient $=-0.018, \mathrm{p}<0.01$ ) indicating that performance is reduced over and above the levels predicted by the Leone and Van Horn (2005) model. This finding is consistent with strong incentives to protect future performance and raises questions as to whether the linear model of discretionary accruals which underpins the Leone and Van Horn model adequately captures accruals management at high levels of pre-managed performance. The incentives related to the protection of future performance and the avoidance of political and public scrutiny are not specific to the Foundation Trust setting and therefore the behaviour of discretionary accruals at high levels of pre-managed performance warrants further investigation in alternative settings

Column 5 shows that when the pre-managed risk ratings are taken together, the results are similar.. Amongst the control variables, there is some variation with the type of Trust. Discretionary accruals are lower in ambulance trusts and higher in mental health and specialist trusts as compared with the reference group of acute Trusts. Location however has no impact, and size, although statistically significant $(p<0.05)$, has no economic significance (coefficient $=0.00$ ).

Taken together our findings are consistent with the management of accruals to avoid regulatory intervention not only in the short term (discretionary accruals are income increasing when there is a small pre-managed deficit) but also in the medium term (discretionary accruals are income decreasing when there is a pre-managed surplus and are more so when the pre-managed surplus is well above intervention triggering thresholds).

Insert Table 4 about here 
Table 5 shows the results for equation 3 which tests for accruals management when the pre-managed prudential borrowing limit is breached and when each component risk rating is 2 , potentially signalling intervention. Discretionary accruals are more positive for a breach of the prudential borrowing limit $(1.6 \%$ of assets, $p<0.01)$ and when the pre-managed I\&E surplus component rating is $2(1.3 \%$ of assets, $p<0.01)$. This suggests that the management of accruals to avoid regulatory intervention is being driven by what could arguably be described as two 'strategic' metrics, the I\&E surplus, which is the headline performance metric for a large range of stakeholders, and the prudential borrowing limit, which has implications for the strategic capacity of the Trust. The I\&E surplus metric also appears to be a tighter constraint (as indicated by the descriptive statistics in Table 1) than for example the EBITDA metric and may therefore be more vulnerable to a poor rating. A low rating on other metrics may be representative of much poorer overall performance and the risk rating may therefore be less amenable to management.

Overall, the levels of additional discretionary accruals at $1-2 \%$ of assets ( $£ 2-4 \mathrm{~m}$ for a Trust with mean assets of $£ 201 \mathrm{~m}$ ) is consistent with audit materiality levels which are conventionally set at $1-2 \%$ of revenue, in accordance with International Auditing Standard (IAS) 320 (para. A7). ${ }^{16}$ Within the context of the margins which feature in Monitor's regulatory regime however these materiality thresholds allow sufficient flexibility for the management of discretionary accruals to influence the final risk rating for the Trust. ${ }^{17}$

As a further test of the management of accruals to avoid intervention we test whether discretionary accruals are managed upwards when pre-managed performance against each component of EBITDA\%, I\&E surplus \%, ROA\% and Liquidity (days) falls within a small range just below the threshold for a component rating of 3 . Significant findings of accruals management in these performance bands would support the argument that discretionary accruals were being managed to avoid intervention. The ranges we choose are $1 \%$ below the EBITDA threshold of $5 \%, 0.5 \%$ below the I\&E threshold of $1 \%, 0.5 \%$ below the ROA threshold of $3 \%$ and 2.5 days below the liquidity threshold of 15 . We also incorporate into this analysis a test of Hypothesis $2 \mathrm{c}$ that small

16 Available at: http://www.ifac.org/system/files/downloads/a018-2010-iaasb-handbook-isa-320.pdf (accessed 10 November 2016)

${ }^{17} \mathrm{We}$ are grateful to Monitor for these insights 
loss avoidance persists within the risk rating regime. The results are shown in Table 6 . They are consistent with those in Table 4 in that accruals are higher for the I\&E surplus, but not for the other metrics. The table additionally provides evidence that discretionary accruals are higher when pre-managed performance falls just below financial breakeven. A coefficient of $0.011(\mathrm{p}<0.01)$ indicates that for a pre-managed deficit of up to $0.5 \%$ revenue ( $£ 1.2 \mathrm{~m}$ for a Trust with mean revenue), discretionary accruals are higher by c. $£ 2 \mathrm{~m}$ (for a Trust with mean assets) thereby providing evidence that, consistent with Hypothesis 2c, discretionary accruals are used to convert small underlying deficits into small reported surpluses.

\section{Insert Table 6 about here}

We supplement the investigation of loss avoidance by conducting a three way analysis of the I\&E surplus margin before and after discretionary accruals. Using the full sample of 518 observations for the four years from 2009-10 to 2012-13, Table 7 shows that of the 105 Trust observations with a pre-managed deficit, $71(40+31)$ reported a surplus, and 31 reported a surplus of more than $1 \%$, the threshold for a component risk rating of 3 . Given the $460(343+117)$ observations with a reported surplus this represents a false positive rate of $15 \%$. Further, of the 343 observations with a reported surplus above $1 \%, 74(43+31)$ had an underlying surplus of less than $1 \%$, representing a false positive rate of $21 \%$. The null hypothesis of an independent distribution of observations is rejected $(\mathrm{Chi}-\mathrm{sq}(4)=156.1, \mathrm{p}=0.000)^{18}$ providing prima facie evidence of the use of discretionary accruals to report an I\&E surplus to achieve regulatory thresholds.

Insert Table 7 about here

\footnotetext{
${ }^{18}$ Although the Chi-square test is limited in its ability to provide information about the strength of the relationships, and is sensitive to the size of the population and to low frequencies of observations, the Chi-square statistic here is well above that required to generate a $p=0.000$ statistic (chi-sq $=20$ ), the population size is modest at 518 observations and the lowest number of observations in a cell is greater than the minimum 5 which would trigger concern.
} 
We also test whether discretionary accruals in the intervals just above the threshold levels for a component risk rating of 3, and just below the threshold for a risk rating of 2, are significantly different from the rest. Evidence of accruals management in these performance bands would undermine the assumption of discretionary accruals management to avoid intervention. The results are shown in Table 8. We find no evidence of additional discretionary accruals in these performance bands.

Insert Table 8 about here

In all the above tables the underlying reduction in reported surpluses/deficits is in the order of $10-11 \%$. This is below the level found by Leone and Van Horn (2005) in US not for profit hospitals (44\%), by Ferreira et al. (2005) in Portuguese municipalities (40-80\%) and by Verbruggen and Christiaens (2012) in Belgian not-forprofit entities (57\%). This lower level, is consistent with the move away from financial breakeven as the principal financial objective, with the integral features of the regulatory regime which discourage gaming, and also with early findings that the higher the proportion of funding obtained from regulated public sources the lower the reduction of underlying surpluses and deficits through the use of discretionary accruals (Greenwood and Tao, 2016).

\subsection{Robustness testing and limitations of analysis}

A number of research design choices have been made in this paper in relation to the estimation of discretionary accruals and the pre-managed risk rating. In this section we discuss these and their implications for our analysis.

For the estimation of discretionary accruals, we chose the Dechow and Dichev (2002) model as amended and applied in Ballantine et al. (2007) for the estimation of discretionary accruals on the grounds that this model delivers higher explanatory power than the modified Jones model (Dechow et al. 1995). However, this modelling approach has been criticised (Wysocki 2009) as being poorly suited to the testing of earnings management on the basis that discretionary accruals made with the intention of smoothing earnings will tend to be classified as nondiscretionary. We therefore test our findings using first, the modified Jones model (Dechow et al. 1995) and second, using 
the approach adopted by Dechow et al. $(2012)^{19}$. We then apply the discretionary accruals we derive to Equations 2 and 3 and in all cases the findings (both coefficients and statistical significance) are similar.

We use a pooled OLS regression to estimate discretionary accruals. An alternative, annual cross-sectional estimation of discretionary accruals delivers similar co-efficients but with stronger significance for some variables. For example, the coefficient on the pre-managed risk rating of 3 is negative, significant and similar to that in Table 4, confirming the pattern of an increasing rate of accruals management with pre-managed financial performance. This lends further weight to the conclusion that protection against future intervention represents a stronger incentive than rewards in the form of greater managerial autonomy. In Table 5, using the OLS regression, we found weak significance (10\%) for the management of discretionary accruals upwards when the ROA and EBITDA component ratings were 2. When discretionary accruals are estimated using a cross-sectional model the co-efficients are again similar but with a stronger significance $(<1 \%)$. There is no change in insignificance attached to a 2 rating of the liquidity metric. This strengthens the proposition that a component rating of 2 may trigger discretionary accruals management.

With respect to the calculation of the pre-managed risk rating, our calculation of the pre-managed liquidity component assumes that all discretionary accruals are working capital accruals. We test the robustness of our findings by assuming that only half of the discretionary accruals are working capital accruals. The results are similar both qualitatively and quantitatively.

Finally, we have sought in this paper to investigate the responsiveness of discretionary accruals to regulatory incentives in the Foundation Trust setting. Our estimation of the pre-managed financial risk rating was based on four of the five component metrics. The plan performance metric, with a weighting of $10 \%$, was omitted as the data was not available. This introduces measurement error into our estimation of the aggregate pre-managed performance rating. However, the probability

\footnotetext{
${ }^{19}$ We identify Trust observations vulnerable to accruals management as those which just pass the threshold for a risk rating of 3 and allow for the reversing out of accruals in the following years 1 and 2.
} 
of a mis-categorisation is $\operatorname{low}^{20}$ and biases our results in favour of our hypothesis $2 \mathrm{a}$ : that accruals are managed upward in order to avoid regulatory intervention.

\section{Discussion and conclusions}

Risk based models of regulation are increasingly being adopted, internationally, for the regulation of public services. This paper investigates variations in discretionary accruals in response to the regulatory incentives associated with such a model of public service delivery, that of NHS Foundation Trusts, where the level of monitoring and intervention is determined by performance against two key financial performance metrics: a financial risk rating and a prudential borrowing limit.

Overall, consistent with prior research and with general public and not-forprofit incentives to signal competence and efficiency in the use of resources, we find that discretionary accruals are managed to reduce the overall variation in reported performance: performance is managed upwards when there is a pre-managed deficit and downwards when there is a pre-managed surplus. However, the level of accruals management is lower than has been found in other not for profit settings, perhaps reflecting the strength of the control environment. Trusts are required to submit quarterly monitoring returns, with increased scrutiny if performance falls below certain thresholds. Few other settings are subject to this level of monitoring at the organisational level though with the rise of risk based regulation we may see the increased use of such systems for public sector organisations. The influence of monitoring strength on public sector financial reporting quality is worthy of further research. We further contribute to the literature by finding that, in addition, discretionary accruals are managed to avoid intervention.. They are performance

${ }^{20}$ The omission of the plan metric in our estimation of the pre-managed risk rating could result in error if the inclusion of the plan metric would result in a change in our classification of a 2 rating to a 3 rating or from a 3 rating to a 2 rating. The probability of this is low.

To result in a misclassification of a Trust as having a financial risk rating of 2 would require a $\%$ of plan rating of 4 combined with a 4 rating on either the I\&E surplus or the ROA metrics and a 2 rating on the EBITDA or liquidity rating, with the balance of the metrics having a 3 rating.

To result in a misclassification of a Trust as a 3 rating would require a \% plan rating of 2 or 1 combined with all other metrics being classified as 3 . Following consultation with auditors and financial representatives of Foundation Trusts we judge this scenario to be unlikely as Trusts aim to protect their performance rating at a level of 3 or above by planning conservatively.

Misclassifications bias our findings in favour of our hypothesis $2 \mathrm{a}$ because misclassification of a Trust as having a pre-managed risk rating of 3 when inclusion of the plan metric would indicate a 2 rating would result in overstatement of discretionary accruals associated with a 3 rating in our model. Similarly, mis-classification of a Trust as having a pre-managed risk rating of 2 when inclusion of the plan metric would indicate a 3 rating would serve to underestimate the discretionary accruals associated with a 2 rating in our model. 
increasing when pre-managed performance is just below the intervention threshold (a risk rating of 2, or when the prudential borrowing limit is breached) and performance decreasing when performance is well above threshold (a risk rating of 4 or 5). The latter finding is consistent with a strong desire to reduce large surpluses and to protect future performance against the possibility of regulatory intervention and suggests that at high levels of performance incentives for good performance, in this case in the form of lower monitoring and potential access to additional resources, are relatively ineffective. It also raises questions about the linear model of discretionary accruals assumed by Leone and Van Horn (2005). Our findings suggest that there may be a non-linear relationship at high levels of pre-managed performance and that further research in other settings would help to refine our understanding of accruals management in not-for-profit and public sector settings.

A further finding is that the incentive to achieve minimum levels of performance in order to avoid intervention has not displaced an aversion to the reporting of small losses. This finding is consistent with prior research in both the public and private sectors, a general aversion to losses which is a feature of the overall regulatory framework, and with the desire to signal competence and efficiency, particularly to a wider stakeholder audience who may be less concerned with the other metrics used by the regulator

Taken together, this additional accruals management demonstrates that the use of an aggregated performance metric with features which aim to mitigate gaming does not preclude accruals management within acceptable audit materiality limits of 1-2\% of revenue. Our findings also demonstrate that incentives to report high levels of financial performance, in the form of additional managerial autonomy, are not so strong as to affect financial reporting quality. In the public and not-for-profit settings the acceptability of stronger incentives for increased surplus reporting for example in the form of remuneration incentives (as investigated in Eldenburg et al, 2004) is debatable and could lead to reduced financial reporting quality. However, as healthcare services continue to be subject to reform, with the proposed unwinding of 'Obama-care' in the US and increased marketization elsewhere, further research into the conditions under which financial reporting quality is affected by incentives for 'better' financial performance would be helpful in informing regulatory design. Comparative studies either internationally or within a setting such as the US where the healthcare providers 
operate across both not for profit and profit sectors, and in a variety of institutional settings, would facilitate a deeper understanding of these issues.

We further find that the management of discretionary accruals is driven by two metrics of strategic significance, the I\&E surplus margin and the prudential borrowing limit. Discretionary accruals are higher, on average, by $1.3 \%$ of total assets (or $£ 2.5 \mathrm{~m}$ for a Trust with mean assets) when the I\&E surplus margin falls below $1 \%$ ( $£ 2.7 \mathrm{~m}$ for a Trust with mean revenue), the potentially intervention triggering threshold for a component risk rating of 2 . Both the scale of the economic effect and the statistical significance of the findings is lower for other components of the risk rating. These findings are consistent both with the wider strategic importance of the I\&E surplus which has significance and meaning to a stakeholder audience which extends far beyond the immediate concerns of the regulator, and with the evidence that the I\&E surplus represents a tighter constraint than other components. This finding also raises the possibility of cognitive bias in the form of 'anchoring' (Tversky and Kahneman 1974) around a long-standing performance measure of wider stakeholder significance for accruals management and/or regulatory design. The design of the financial risk rating inevitably involves assumptions about a typical 'business model' for Foundation Trusts. However, whilst there has been a long history of familiarity with the I\&E surplus within the National Health Service, there has been less visibility and focus on for example EBITDA and ROA. The possibility of 'anchoring' around the I\&E measure and financial break-even warrants further research.

Internationally, our findings have relevance where public and not-for -profit healthcare systems adopt performance measurement which involves financial monitoring either by external agencies or internally as an instrument of management control. In the US, for example, there are numerous hospital systems such as Kaiser Permanente which operates 37 hospitals in California. Elsewhere, such as in Australia, New Zealand and Canada, multi-dimensional balanced scorecard systems, which variously draw on World Health Organisation's PATH system (WHO 2007), have been adopted to compare and monitor hospital performance. This suggests the possibility of further research in alternative settings, (including the possibility of comparative studies both internationally and across the not-for-profit, for-profit and public sectors), into the impact of monitoring, both internal and external, on financial reporting quality. 
Our findings have some practice and policy implications. Whilst accruals management around regulatory targets is unlikely to be eliminated further investment in cost effective measures to improve financial reporting quality would enhance regulatory effectiveness and facilitate more effective allocation of resources across the healthcare sector: intervention would be more timely when underlying performance is poor and there would be less scope for Trusts to disguise their potential for service development when underlying performance is strong. Such measures might include additional audit guidance, a review of audit materiality thresholds, and more refined regulatory monitoring of accruals. In a more marketised NHS other measures might also include a strengthening of the incentives to report good financial performance which, subject to wider political considerations, would mitigate the incentives to disguise surpluses. These considerations are particularly relevant when, as at present, there are considerable pressures on public spending and the funding of the health service. 


\section{References}

Ballantine, J., Forker, J. and Greenwood, M., 2007. Earnings management in English NHS hospital trusts. Financial Accountability and Management, 23 (4), 421-440.

Ballantine, J., Forker, J. and Greenwood, M., 2008. The governance of CEO incentives in English NHS hospital trusts. Financial Accountability and Management, 24(4), $385-410$.

Bellé, N., 2015. Performance-related pay and the crowding out of motivation in the public sector: a randomized field experiment. Public Administration Review, 75 (2), 230-241.

Black, J. and Baldwin, R., 2010. Really responsive risk based regulation. Law and Policy 32(2), 181-213.

Blöndal, J., 2003. Accrual accounting and budgeting: key issues and recent developments. OECD Journal on Budgeting, 3(1) 43-60.

Burgstahler, D. and Dichev, I., 1997. Earnings management to avoid earnings decreases and losses. Journal of Accounting and Economics, 24 (1), 99-126.

Chung, R., Firth, M. and Kim, J-B., 2002. Institutional monitoring and opportunistic earnings management. Journal of Corporate Finance, 8(1), 29-48.

Cuganesan, S. Guthrie, J. and Vranic, V., 2014. The riskiness of public sector performance measurement: a review and research agenda. Financial Accountability and Management, 30(3), 279-302.

Dechow, P., Sloan, R. and Sweeney, A., 1995. Detecting earnings management. Accounting Review, 70 (2), 193-225.

Dechow, P. and Dichev, I., 2002. The quality of accruals and earnings: the role of accrual estimation errors. Accounting Review, 77 (4, Suppl), 35-59.

Dechow, P., Ge, W. and Schrand, C., 2010. Understanding earnings quality: a review of the proxies, their determinants and their consequences. Journal of Accounting and Economics, 50 (2/3), 344-401. 
Dechow, P., Hutton, A., Kim, J. and Sloan, R. 2012. Detecting earnings management: a new approach. Journal of Accounting Research, 50(2), 275-334.

Eldenburg, L., Hermalin, B., Weisbach, M. and Wosinka, M., 2004. Governance performance objectives and organizational form: evidence from hospitals. Journal of Corporate Finance, 10 (4), 527-548.

Ferreira, A., Carvalho, J. and Pinho, F., 2013. Earnings management around zero: a motivation to local politician signalling competence. Public Management Review 15(5), 1-30.

Georgellis, Y., Iossa, E. and Tabvuna, V., 2011. Crowding out intrinsic motivation in the public sector. Journal of Public Administration Research and Theory, 21(3), 473-493.

Greenwood, M. and Tao, L., 2016. External monitoring and financial reporting quality: evidence from universities. Working paper presented at the American Accounting Association Annual Conference, New York, August 2016.

Health and Social Care (Community Health and Standards) Act 2003, Chapter 43. London: The Stationery Office. Also available at: http://www.legislation.gov.uk/ukpga/2003/43/contents

Health and Social Care Act 2012, Chapter 7. London: The Stationery Office.

Hoerger, T., 1991. 'Profit' variability in for-profit and not-for-profit hospitals. Journal of Health Economics, 10 (3), 259-289.

Hood, C., 1991. Public Management for All Seasons. Public Administration, 69 (1), 3 19.

Hood, C., 1995. The 'new public management' in the 1980s: Variations on a theme. Accounting, Organizations and Society, 20 (2/3), 93-109.

House of Commons, 2011. Health Expenditure: international comparisons. $\mathrm{SN} / \mathrm{SG} / 2584$. 
International Public Sector Accounting Standards Board® (IPSASB®), 2014. Conceptual Framework for General Purpose Financial Reporting by Public Sector Entities.

http://www.ifac.org/publications-resources/conceptual-framework-generalpurpose-financial-reporting-public-sector-enti-8 (Accessed 27 November 2015)

Jegers, M., 2010. The effect of board-manager agency conflicts on non-profit organisations' earnings and cost allocation manipulations. Accounting and Business Research, 40(5), 407-419.

Jones, J., 1991. Earnings management during import relief investigations. Journal of Accounting Research, 29 (2), 193-228.

Jones, C. and Roberts, A., 2006. Management of financial information in charitable organizations: the case of joint-cost allocations. Accounting Review, 81 (1), 159178.

Jørgensen, T. and Anderson, L., 2011. An aftermath of NPM: regained relevance of public values and public service motivation. In: T. Christensen and P. Laegrid, eds. The Ashgate Research Companion to New Public Management. Dorchester: Ashgate Publishing Limited, 335-348.

Kasznik, R., 1999. On the association between voluntary disclosure and earnings management. Journal of Accounting Research, 37(1), 57-81.

Kothari, S., Leone, A., Wasley, C., 2005. Performance matched discretionary accrual measures. Journal of Accounting and Economics, 39(1), 163-197.

Krishnan, R., Yetman, M. and Yetman, R., 2006. Expense misreporting in nonprofit organizations. Accounting Review, 81 (2), 399-420.

Krishnan, R. and Yetman, M., 2011. Institutional drivers of reporting decisions in nonprofit hospitals. Journal of Accounting Research, 49 (4), 1001-1039.

Lapsley, I. and Schofield, J., 2009. The NHS at 60: adapting and surviving. Financial Accountability and Management, 25(4), 367-372. 
Leone, A. and Van Horn, R., 2005. How do non-profit hospitals manage earnings? Journal of Health Economics, 24 (4), 815-837.

Marquardt, C. and Wiedman, C., 2004. How are earnings managed? An examination of specific accruals. Contemporary Accounting Research, 21 (2), 461-491.

McNichols, M., 2002. Discussion of the quality of accruals and earnings: the role of accrual estimation errors. Accounting Review, 77 (Suppl.), 61-69.

Mensah, Y., Considine, J. and Oakes, L., 1994. Statutory insolvency regulations and earnings management in the prepaid healthcare industry. Accounting Review, 69(1), 70-95.

Mitra, S. and Cready, W., 2005. Institutional Stock Ownership, Accrual Management, and Information Environment. Journal of Accounting, Auditing \& Finance, 20(3), 257-286

Monitor, 2009a. Prudential Borrowing Code for NHS Foundation Trusts. IRG 04/09.

Monitor, 2009b. Compliance Framework 2009/10. London. IRG 05/09.

Monitor, 2011. Compliance Framework 2011/12. London. IRG 04/11.

Monitor, 2013. Compliance Framework 2013/14. London. IRG 07/13.

National Audit Office, 2016. Reports on Department of Health, NHS England and NHS Foundation Trusts' consolidated accounts 2015-16. Available at: https://www.nao.org.uk/report/reports-on-department-of-health-nhs-englandand-nhs-foundation-trusts-consolidated-accounts-2015-16/ [Accessed 31 October 2016]

National Health Service and Community Care Act 1990, Chapter 19. London: The Stationery Office.

National Health Service Act 2006, Chapter 41. London: The Stationery Office.

Navissi, F., 1999. Earnings management under price regulation. Contemporary Accounting Research, 16(2), 281-304. 
NHS Trust Development Authority (2016). Delivering the Forward View Annex 7. (available at: http://www.ntda.nhs.uk/wp-content/uploads/2015/12/Annex-7NHS-TDA-2016-17-TFMS-Plan-Guidance.pdf) (accessed 17 March 2017)

Pilcher, R. and Van der Zahn, M., 2010. Local Governments, Unexpected Depreciation and Financial Performance Adjustment. Financial Accountability \& Management, 26 (3), 299-324.

Pollitt, C. and Bouckaert, G., 2011. Public Management Reform - A Comparative Analysis: New Public Management, Governance and the Neo-Weberian State. 3rd ed. Oxford: Oxford University Press.

Stalebrink, O., 2007. An investigation of discretionary accruals and surplus-deficit management: evidence from Swedish municipalities. Financial Accountability \& Management, 23 (4), 441-458.

The Work Foundation, 2014. A review of the evidence, impact and value for money of performance related pay in the public sector. Available at: http://www.theworkfoundation.com/Reports/375/A-Review-of-the-Evidenceon-the-Impact-Effectiveness-and-Value-For-Money-of-PerformanceRelatedPay-in-the-Public-Sector (Accessed 27 November 2015)

Tversky, A. and Kahneman, D., 1974. Judgment under Uncertainty: Heuristics and Biases. Science, 185, (4157), 1124-1131.

Verbruggen, S. and Christiaens, J., 2012. Do non-profit organizations manage earnings toward zero profit and does governmental financing play a role? Canadian Journal of Administrative Sciences, 29 (3), 205-217.

Wongsunwai, W., 2013. The Effect of External Monitoring on Accrual-Based and Real Earnings Management: Evidence from Venture-Backed Initial Public Offerings. Contemporary Accounting Research, 30(1), 296-324.

WHO (World Health Organization) 2007. Performance Assessment Tool for Quality Improvement in Hospitals. Available at: http://www.euro.who.int/_data/assets/pdf_file/0003/103728/E89742.pdf (accessed 15 November 2016) 
Wysocki, P., 2009. Assessing earnings and accruals quality: US and international evidence. Unpublished working paper. Cambridge: MIT Sloan School of Management. 
Table 1 Descriptive statistics

\begin{tabular}{|c|c|c|c|c|c|c|c|c|}
\hline Variable & No. obs. & Mean & Std.Devn. & Min. & Max. & Median & Skewness & Kurtosis \\
\hline Total income $£ 000$ & 332 & 266,671 & 180,351 & 21,024 & $1,168,963$ & 222,987 & 2.120 & 8.546 \\
\hline Total as sets $£ 000$ & 332 & 201,568 & 158,158 & 9,885 & $1,135,903$ & 155,625 & 2.777 & 13.737 \\
\hline Staff costs $£ 000$ & 332 & 166,415 & 99,594 & 10,488 & 650,127 & 146,322 & 1.812 & 7.554 \\
\hline EBITDA $£ 000$ & 332 & 17,013 & 15,877 & $-19,749$ & 106,505 & 13,364 & 2.286 & 10.409 \\
\hline EBITDA/TI \% & 332 & 6.096 & 2.907 & -9.504 & 17.545 & 5.972 & -1.007 & 8.612 \\
\hline I\&E surplus & 332 & 4,374 & 10,080 & $-45,772$ & 93,574 & 3,300 & 2.918 & 32.039 \\
\hline I\&E surplus/TI \% & 332 & 1.557 & 3.521 & -22.027 & 25.254 & 1.409 & -0.542 & 19.733 \\
\hline Liquidity days & 332 & 28.907 & 26.276 & -32.669 & 200.311 & 26.315 & 1.266 & 8.516 \\
\hline Return on assets & 332 & 3.394 & 6.421 & -31.851 & 41.727 & 4.210 & -0.640 & 11.785 \\
\hline Net current assets $£ 000$ & 332 & 11,230 & 14,908 & $-23,913$ & 91,183 & 8,018 & 1.278 & 6.060 \\
\hline Receivables $£ 000$ & 332 & 11,363 & 10,693 & 1,349 & 68,546 & 8,174 & 2.795 & 12.107 \\
\hline Inventory $£ 000$ & 332 & 3,104 & 3,572 & 0 & 19,132 & 2,316 & 1.941 & 7.311 \\
\hline Payables $£ 000$ & 332 & 25,086 & 19,881 & 2,031 & 147,757 & 19,037 & 2.608 & 12.298 \\
\hline Depreciation $£ 000$ & 332 & 7,441 & 6,211 & 429 & 42,535 & 5,674 & 2.475 & 11.304 \\
\hline Long term provisions $£ 000$ & 332 & 1,811 & 2,326 & 0 & 20,368 & 1,030 & 3.613 & 23.501 \\
\hline Bad debt expense & 332 & 311 & 990 & $-4,426$ & 9,637 & 107 & 3.660 & 35.346 \\
\hline
\end{tabular}


Table 2

Pairwise correlation statistics: pre-managed component risk ratings

\begin{tabular}{|c|c|c|c|c|c|}
\hline Indicators & EBITDA rating & I\&E rating & ROA rating & Liquidity rating & PBL indicatol \\
\hline $\begin{array}{l}\text { EBITDA rating } \\
(1-5)\end{array}$ & 1.00 & & & & \\
\hline $\begin{array}{l}\text { I\&E rating } \\
(1-5)\end{array}$ & $\begin{array}{c}0.64 \\
(0.00)\end{array}$ & 1.00 & & & \\
\hline $\begin{array}{l}\text { ROA rating } \\
(1-5)\end{array}$ & $\begin{array}{c}0.52 \\
(0.00)\end{array}$ & $\begin{array}{c}0.73 \\
(0.00)\end{array}$ & 1.00 & & \\
\hline $\begin{array}{l}\text { Liquidity rating } \\
(1-5)\end{array}$ & $\begin{array}{c}0.26 \\
(0.00)\end{array}$ & $\begin{array}{c}0.43 \\
(0.00)\end{array}$ & $\begin{array}{c}0.32 \\
(0.00)\end{array}$ & 1.00 & \\
\hline PBL indicator & $\begin{array}{l}-0.37 \\
(0.00) \\
\end{array}$ & $\begin{array}{l}-0.75 \\
(0.00) \\
\end{array}$ & $\begin{array}{l}-0.60 \\
(0.00) \\
\end{array}$ & $\begin{array}{l}-0.41 \\
(0.00)\end{array}$ & 1.00 \\
\hline
\end{tabular}


Table 3

Descriptive statistics of discretionary accruals

\begin{tabular}{|c|c|c|c|c|c|c|c|c|}
\hline $\begin{array}{c}\text { Weighted Rating } \\
\text { (Pre-managed) }\end{array}$ & $\mathbf{N}$ & mean & $\begin{array}{c}\text { T-test } \\
\text { mean }=0\end{array}$ & sd & $\min$ & $\max$ & median & $\overline{\text { skewness }}$ \\
\hline 1 & 35 & 0.008 & 0.160 & 0.052 & -0.097 & 0.153 & 0.004 & 0.700 \\
\hline 2 & 113 & 0.011 & 0.000 & 0.025 & -0.055 & 0.124 & 0.010 & 1.404 \\
\hline 3 & 125 & -0.003 & 0.145 & 0.019 & -0.082 & 0.049 & -0.002 & -0.533 \\
\hline 4 or 5 & 59 & -0.016 & 0.002 & 0.037 & -0.140 & 0.126 & -0.017 & 0.068 \\
\hline Total & 332 & 0.001 & 0.759 & 0.031 & -0.140 & 0.153 & 0.000 & 0.530 \\
\hline
\end{tabular}




\section{Table 4}

Estimation results for discretionary accruals and pre-managed risk rating

\begin{tabular}{|c|c|c|c|c|c|c|}
\hline & & (1) & (2) & (3) & (4) & (5) \\
\hline \multirow[t]{5}{*}{ Pre-mSurp } & Pre-managed surplus & $-0.110 * * *$ & $-0.111^{* * *}$ & $-0.114 * * *$ & $-0.100 * * *$ & $-0.0801 * * *$ \\
\hline & & $(0.0383)$ & $(0.0358)$ & $(0.0388)$ & $(0.0326)$ & $(0.0258)$ \\
\hline & Pre-managed risk rating 1 & 0.00687 & & & & 0.0134 \\
\hline & & $(0.00827)$ & & & & $(0.00877)$ \\
\hline & Pre-managed risk rating 2 & & $0.0107^{* * *}$ & & & $0.0110 * * *$ \\
\hline \multirow[t]{5}{*}{ Rating } & & & $(0.00332)$ & & & $(0.00319)$ \\
\hline & Pre-managed risk rating 3 & & & -0.00491 & & \\
\hline & & & & $(0.00296)$ & & \\
\hline & Pre-managed risk rating $>=4$ & & & & $-0.0182 * * *$ & $-0.0139 * *$ \\
\hline & & & & & $(0.00632)$ & $(0.00599)$ \\
\hline Type & Acute Specialist & $0.0151 * *$ & $0.0168^{* *}$ & $0.0142 * *$ & $0.0216^{* * *}$ & $0.0232 * * *$ \\
\hline \multirow{7}{*}{$\begin{array}{l}\text { Base } \\
\text { group: } \\
\text { acute }\end{array}$} & & $(0.00625)$ & $(0.00667)$ & $(0.00625)$ & $(0.00779)$ & $(0.00764)$ \\
\hline & Acute Teaching & -0.000960 & -0.00221 & -0.00126 & -0.00217 & -0.00151 \\
\hline & & $(0.00523)$ & $(0.00512)$ & $(0.00524)$ & $(0.00518)$ & $(0.00478)$ \\
\hline & Ambulance & $-0.0772 * * *$ & $-0.0758 * * *$ & $-0.0808 * * *$ & $-0.0618 * * *$ & $-0.0625^{* * *}$ \\
\hline & & $(0.0200)$ & $(0.0212)$ & $(0.0207)$ & $(0.0213)$ & $(0.0216)$ \\
\hline & Mental Health & $0.0180 * * *$ & $0.0172 * * *$ & $0.0174 * * *$ & $0.0188 * * *$ & $0.0186 * * *$ \\
\hline & & $(0.00452)$ & $(0.00444)$ & $(0.00449)$ & $(0.00481)$ & $(0.00470)$ \\
\hline Region & Midlands & 0.00122 & 0.00216 & 0.00179 & 0.00176 & 0.00288 \\
\hline \multirow{5}{*}{$\begin{array}{l}\text { Base } \\
\text { group: } \\
\text { London }\end{array}$} & & $(0.00583)$ & $(0.00582)$ & $(0.00580)$ & $(0.00598)$ & $(0.00611)$ \\
\hline & North & 0.00542 & 0.00565 & 0.00594 & 0.00479 & 0.00645 \\
\hline & & $(0.00542)$ & $(0.00518)$ & $(0.00535)$ & $(0.00549)$ & $(0.00544)$ \\
\hline & South & 0.00704 & 0.00863 & 0.00844 & 0.00569 & 0.00750 \\
\hline & & $(0.00581)$ & $(0.00567)$ & $(0.00563)$ & $(0.00607)$ & $(0.00612)$ \\
\hline \multirow[t]{2}{*}{$D A_{i t-1}$} & Prior year discretionary accruals & -0.0376 & -0.0689 & -0.0529 & -0.0401 & -0.0366 \\
\hline & & $(0.0914)$ & $(0.0970)$ & $(0.0975)$ & $(0.0933)$ & $(0.0857)$ \\
\hline \multirow[t]{2}{*}{ RepSurp $_{i t-1}$} & Prior year reported performance & $0.0780 * * *$ & $0.0747^{* * *}$ & $0.0755^{* * * *}$ & $0.0801 * * *$ & $0.0877 * * *$ \\
\hline & & $(0.0267)$ & $(0.0273)$ & $(0.0263)$ & $(0.0266)$ & $(0.0286)$ \\
\hline \multirow[t]{9}{*}{$T I_{i t-1}$} & Log of prior year total income & $3.04 \mathrm{e}-08 * *$ & $2.73 \mathrm{e}-08^{* *}$ & $3.00 \mathrm{e}-08^{* *}$ & $2.69 \mathrm{e}-08^{*}$ & $2.74 \mathrm{e}-08^{* *}$ \\
\hline & & $(1.44 \mathrm{e}-08)$ & $(1.35 \mathrm{e}-08)$ & $(1.40 \mathrm{e}-08)$ & $(1.40 \mathrm{e}-08)$ & $(1.34 \mathrm{e}-08)$ \\
\hline & Year & Yes & Yes & Yes & Yes & Yes \\
\hline & Constant & $-0.0201 * * *$ & $-0.0229 * * *$ & $-0.0177 * *$ & $-0.0162 * *$ & $-0.0239 * * *$ \\
\hline & & $(0.00754)$ & $(0.00764)$ & $(0.00772)$ & $(0.00779)$ & $(0.00755)$ \\
\hline & Observations & 332 & 332 & 332 & 332 & 332 \\
\hline & R-squared & 0.212 & 0.231 & 0.214 & 0.237 & 0.259 \\
\hline & & \multicolumn{5}{|c|}{ Cluster robust standard errors in parentheses } \\
\hline & & \multicolumn{5}{|c|}{$* * * \mathrm{p}<0.01, * * \mathrm{p}<0.05, * \mathrm{p}<0.1$} \\
\hline
\end{tabular}

Dependent variable: DAit Discretionary accruals 
Table 5

Estimation results for discretionary accruals and the prudential borrowing limit and premanaged component risk ratings of 2

\begin{tabular}{|c|c|c|c|c|c|c|}
\hline & & (1) & (2) & (3) & (4) & (5) \\
\hline \multirow[t]{2}{*}{ Pre-mSurp } & Pre-managed surplus & $-0.112 * * *$ & $-0.114 * * *$ & $-0.115 * * *$ & $-0.119 * * *$ & $-0.0971 * * *$ \\
\hline & & $(0.0400)$ & $(0.0366)$ & $(0.0384)$ & $(0.0403)$ & $(0.0319)$ \\
\hline \multirow[t]{2}{*}{ Rating } & EBITDA \% & $0.00627^{*}$ & & & & \\
\hline & & $(0.00342)$ & & & & \\
\hline \multirow{8}{*}{$\begin{array}{l}1 \text { if Pre- } \\
\text { managed } \\
\text { component } \\
\text { rating }=2 \text { or } \\
\text { if prudential } \\
\text { borrowing } \\
\text { limit is } \\
\text { breached }\end{array}$} & I\&Es urplus \% & & $0.0129 * * *$ & & & \\
\hline & & & $(0.00304)$ & & & \\
\hline & ROA\% & & & $0.00639 *$ & & \\
\hline & & & & $(0.00343)$ & & \\
\hline & Liquidity (days) & & & & -0.00111 & \\
\hline & & & & & $(0.00735)$ & \\
\hline & Prudential borrowing limit & & & & & $0.0155 * * *$ \\
\hline & & & & & & $(0.00390)$ \\
\hline \multirow{8}{*}{$\begin{array}{l}\text { Type } \\
\text { Base group: } \\
\text { Acute }\end{array}$} & Acute Specialist & $0.0159 * *$ & $0.0184 * * *$ & $0.0147 * *$ & $0.0146^{* *}$ & $0.0215 * * *$ \\
\hline & & $(0.00647)$ & $(0.00672)$ & $(0.00658)$ & $(0.00642)$ & $(0.00733)$ \\
\hline & Acute Teaching & -0.00203 & -0.00249 & -0.000114 & -0.00155 & -0.00179 \\
\hline & & $(0.00532)$ & $(0.00501)$ & $(0.00535)$ & $(0.00541)$ & $(0.00526)$ \\
\hline & Ambulance & $-0.0763 * * *$ & $-0.0724 * * *$ & $-0.0766 * * *$ & $-0.0778 * * *$ & $-0.0697 * * *$ \\
\hline & & $(0.0205)$ & $(0.0209)$ & $(0.0207)$ & $(0.0204)$ & $(0.0208)$ \\
\hline & Mental Health & $0.0165^{* * *}$ & $0.0198 * * *$ & $0.0176 * * *$ & $0.0177 * * *$ & $0.0192 * * *$ \\
\hline & & $(0.00463)$ & $(0.00457)$ & $(0.00456)$ & $(0.00449)$ & $(0.00459)$ \\
\hline \multirow{6}{*}{$\begin{array}{l}\text { Region } \\
\text { Base group: } \\
\text { London }\end{array}$} & Midlands & 0.00128 & 0.00391 & 0.00148 & 0.00108 & 0.00198 \\
\hline & & $(0.00585)$ & $(0.00560)$ & $(0.00564)$ & $(0.00589)$ & $(0.00623)$ \\
\hline & North & 0.00477 & 0.00700 & 0.00501 & 0.00487 & 0.00498 \\
\hline & & $(0.00547)$ & $(0.00510)$ & $(0.00519)$ & $(0.00554)$ & $(0.00563)$ \\
\hline & South & 0.00732 & 0.00820 & 0.00727 & 0.00703 & 0.00716 \\
\hline & & $(0.00584)$ & $(0.00560)$ & $(0.00556)$ & $(0.00584)$ & $(0.00620)$ \\
\hline \multirow[t]{2}{*}{$D A_{i t-1}$} & Prior yr discretionary accs & -0.0504 & -0.0632 & -0.0557 & -0.0508 & -0.0489 \\
\hline & & $(0.0982)$ & $(0.0981)$ & $(0.0981)$ & $(0.0982)$ & $(0.0965)$ \\
\hline \multirow[t]{2}{*}{ RepSurp $_{i t-1}$} & Prior yr reported performance & $0.0723 * * *$ & $0.0750 * * *$ & $0.0753 * * *$ & $0.0734 * * *$ & $0.0834 * * *$ \\
\hline & & $(0.0265)$ & $(0.0280)$ & $(0.0268)$ & $(0.0257)$ & $(0.0271)$ \\
\hline \multirow[t]{2}{*}{$T I_{i t-1}$} & Prior yr total income & $3.29 \mathrm{e}-08 * *$ & $3.30 \mathrm{e}-08 * *$ & $2.57 \mathrm{e}-08^{*}$ & $2.96 \mathrm{e}-08^{* *}$ & $2.84 \mathrm{e}-08^{* *}$ \\
\hline & & $(1.47 \mathrm{e}-08)$ & $(1.34 \mathrm{e}-08)$ & $(1.38 \mathrm{e}-08)$ & $(1.46 \mathrm{e}-08)$ & $(1.30 \mathrm{e}-08)$ \\
\hline Year & & Yes & Yes & Yes & Yes & Yes \\
\hline \multirow[t]{2}{*}{ Constant } & & $-0.0205^{* *}$ & $-0.0264 * * *$ & $-0.0193 * *$ & $-0.0186 * *$ & $-0.0302 * * *$ \\
\hline & & $(0.00797)$ & $(0.00754)$ & $(0.00755)$ & $(0.00780)$ & $(0.00819)$ \\
\hline \multicolumn{2}{|l|}{ Observations } & 332 & 332 & 332 & 332 & 332 \\
\hline \multirow[t]{3}{*}{ R-squared } & & 0.215 & 0.239 & 0.216 & 0.209 & 0.250 \\
\hline & & \multicolumn{5}{|c|}{ Cluster robust standard errors in parentheses } \\
\hline & & \multicolumn{5}{|c|}{$* * * \mathrm{p}<0.01, * * \mathrm{p}<0.05, * \mathrm{p}<0.1$} \\
\hline
\end{tabular}

Dependent variable: DAit Discretionary accruals 
Table 6

Discretionary accruals when component ratings are just below a risk rating of 3 and the I/E surplus is just below breakeven.

\begin{tabular}{|c|c|c|c|c|c|}
\hline & & (1) & (2) & (3) & (4) \\
\hline VARIABLES & & DA & DA & DA & DA \\
\hline \multirow[t]{2}{*}{ Pre-mSurp } & Pre-Managed Surplus(AFP) & $-0.118 * * *$ & $-0.117 * * *$ & $-0.118 * * *$ & $-0.119 * * *$ \\
\hline & & $(0.0399)$ & $(0.0387)$ & $(0.0399)$ & $(0.0403)$ \\
\hline \multirow{10}{*}{$\begin{array}{c}\text { Comp } \\
\text { Individual } \\
\text { component } \\
\text { metrics }\end{array}$} & EBITDA, $1 \%$ below rating 3 & 0.00221 & & & \\
\hline & & $(0.00392)$ & & & \\
\hline & I\&E surplus, $0.5 \%$ below rating 3 & & $0.0111 * * *$ & & \\
\hline & & & $(0.00295)$ & & \\
\hline & I\&E surplus, $0.5 \%$ below breakeven & & $0.0111 * * *$ & & \\
\hline & & & $(0.00361)$ & & \\
\hline & ROA, $0.5 \%$ below rating 3 & & & 0.00282 & \\
\hline & & & & $(0.00565)$ & \\
\hline & Liquidity, 2.5 days below rating 3 & & & & -0.00111 \\
\hline & & & & & $(0.00735)$ \\
\hline \multirow{8}{*}{$\begin{array}{c}\text { Type } \\
\text { Base group: } \\
\text { acute }\end{array}$} & Acute Specialist & $0.0148 * *$ & $0.0163^{* *}$ & $0.0147 * *$ & $0.0146^{* *}$ \\
\hline & & $(0.00644)$ & $(0.00660)$ & $(0.00640)$ & $(0.00642)$ \\
\hline & Acute Teaching & -0.00166 & -0.00216 & -0.00140 & -0.00155 \\
\hline & & $(0.00540)$ & $(0.00546)$ & $(0.00541)$ & $(0.00541)$ \\
\hline & Ambulance & $-0.0775 * * *$ & $-0.0754 * * *$ & $-0.0776^{* * *}$ & $-0.0778 * * *$ \\
\hline & & $(0.0203)$ & $(0.0207)$ & $(0.0204)$ & $(0.0204)$ \\
\hline & Mental Health & $0.0175^{* * *}$ & $0.0189 * * *$ & $0.0177 * * *$ & $0.0177 * * *$ \\
\hline & & $(0.00462)$ & $(0.00455)$ & $(0.00453)$ & $(0.00449)$ \\
\hline \multirow{6}{*}{$\begin{array}{c}\text { Region } \\
\text { Base group: } \\
\text { London }\end{array}$} & Midlands & 0.001000 & 0.00292 & 0.00109 & 0.00108 \\
\hline & & $(0.00582)$ & $(0.00577)$ & $(0.00585)$ & $(0.00589)$ \\
\hline & North & 0.00472 & 0.00585 & 0.00475 & 0.00487 \\
\hline & & $(0.00547)$ & $(0.00523)$ & $(0.00540)$ & $(0.00554)$ \\
\hline & South & 0.00697 & 0.00775 & 0.00693 & 0.00703 \\
\hline & & $(0.00569)$ & $(0.00564)$ & $(0.00580)$ & $(0.00584)$ \\
\hline \multirow[t]{2}{*}{$D A_{i t-1}$} & Prior yr discretionary accruals & -0.0503 & -0.0573 & -0.0511 & -0.0508 \\
\hline & & $(0.0979)$ & $(0.0964)$ & $(0.0980)$ & $(0.0982)$ \\
\hline \multirow[t]{2}{*}{$\operatorname{RepSurp}_{i t-1}$} & Prior yr reported surplus & $0.0737 * * *$ & $0.0751^{* * *}$ & $0.0741^{* * *}$ & $0.0734 * * *$ \\
\hline & & $(0.0262)$ & $(0.0272)$ & $(0.0261)$ & $(0.0257)$ \\
\hline \multirow[t]{2}{*}{$T I_{i t-1}$} & Log of prior yr total income & $2.99 \mathrm{e}-08 * *$ & $2.94 \mathrm{e}-08 * *$ & $2.91 \mathrm{e}-08^{* *}$ & $2.96 \mathrm{e}-08^{* *}$ \\
\hline & & $(1.45 \mathrm{e}-08)$ & $(1.39 \mathrm{e}-08)$ & $(1.44 \mathrm{e}-08)$ & $(1.46 \mathrm{e}-08)$ \\
\hline Year & Year Control & Yes & Yes & Yes & Yes \\
\hline \multirow[t]{2}{*}{ Constant } & & $-0.0189 * *$ & $-0.0223^{* * *}$ & $-0.0186^{* *}$ & $-0.0186^{* *}$ \\
\hline & & $(0.00776)$ & $(0.00761)$ & $(0.00774)$ & $(0.00780)$ \\
\hline Observations & & 332 & 332 & 332 & 332 \\
\hline \multirow[t]{3}{*}{ R-squared } & & 0.210 & 0.225 & 0.209 & 0.209 \\
\hline & & \multicolumn{3}{|c|}{ Cluster robust standard errors in parentheses } & \\
\hline & & $* * * \mathrm{p}<0.01, * *$ & $0.05, * \mathrm{p}<0.1$ & & \\
\hline
\end{tabular}

Dependent variable: DAit Discretionary accruals 
Table 7

Comparison of I\&E surplus margin before and after discretionary accruals

\begin{tabular}{lc|ccc|c}
\hline \multirow{2}{*}{ I\&E Surplus \% } & & \multicolumn{3}{|c|}{ Reported } & \\
\hline \multirow{2}{*}{ Before discretionary accruals } & $\mathbf{0}$ & 34 & $\mathbf{0 - 1}$ & $>=\mathbf{1}$ & Total \\
\cline { 2 - 6 } Total & $>=\mathbf{1}$ & 8 & 40 & 31 & 105 \\
& & $\mathbf{5 8}$ & $\mathbf{1 1 7}$ & $\mathbf{3 4 3}$ & $\mathbf{5 1 8}$ \\
\hline
\end{tabular}

Pearson Chi2(4) $=156.1, p=0.000$.

Note: An I\&E surplus margin of less $1 \%$ is associated with a component risk rating of 2 
Table 8

Estimation results for discretionary accruals and pre-managed performance: additional test of inference that accruals management is in response to the incentive to avoid regulatory intervention ${ }^{\dagger}$

\begin{tabular}{|c|c|c|c|c|c|}
\hline & & (1) & (2) & (3) & (4) \\
\hline \multicolumn{2}{|c|}{ VARIAB LES } & DA & DA & DA & DA \\
\hline \multirow[t]{2}{*}{ Pre-mSurp } & Pre-Managed Surplus & $-0.119 * * *$ & $-0.113 * * *$ & $-0.119 * * *$ & $-0.119 * * *$ \\
\hline & & $(0.0407)$ & $(0.0380)$ & $(0.0401)$ & $(0.0403)$ \\
\hline \multirow{16}{*}{$\begin{array}{c}\text { Comp } \\
\text { Individual } \\
\text { components } \\
\text { of the risk } \\
\text { rating }\end{array}$} & EBITDA, $1 \%$ above rating 3 & -0.00105 & & & \\
\hline & & $(0.00257)$ & & & \\
\hline & EBITDA, $1 \%$ below rating 2 & -0.00234 & & & \\
\hline & & $(0.0358)$ & & & \\
\hline & Reporting surplus, $0.5 \%$ above rating 3 & & -0.00253 & & \\
\hline & & & $(0.00399)$ & & \\
\hline & Reporting surplus, $0.5 \%$ below rating 2 & & $0.0323^{*}$ & & \\
\hline & & & $(0.0183)$ & & \\
\hline & ROA, $0.5 \%$ above rating 3 & & & 0.000156 & \\
\hline & & & & $(0.00625)$ & \\
\hline & ROA, $0.5 \%$ below rating 2 & & & -0.00118 & \\
\hline & & & & $(0.00574)$ & \\
\hline & Liquidity, 2.5 days above rating 3 & & & & $0.00846^{*}$ \\
\hline & & & & & $(0.00456)$ \\
\hline & Liquidity, 2.5 days below rating 2 & & & & -0.00464 \\
\hline & & & & & $(0.00915)$ \\
\hline \multirow[t]{2}{*}{$D A_{i t-1}$} & Prior yr discretionary accruals & -0.0510 & -0.0488 & -0.0504 & -0.0521 \\
\hline & & $(0.100)$ & $(0.0995)$ & $(0.0981)$ & $(0.0980)$ \\
\hline \multirow[t]{2}{*}{$\operatorname{RepSurp}_{i t-1}$} & Prior yr reported surplus & $0.0743 * * *$ & $0.0757 * * *$ & $0.0738 * * *$ & $0.0724 * * *$ \\
\hline & & $(0.0263)$ & $(0.0269)$ & $(0.0261)$ & $(0.0255)$ \\
\hline \multirow[t]{2}{*}{$T I_{i t-1}$} & Prior yr total income & $2.91 \mathrm{e}-08 * *$ & $3.17 \mathrm{e}-08^{* *}$ & $2.93 \mathrm{e}-08 * *$ & $2.79 \mathrm{e}-08^{*}$ \\
\hline & & $(1.44 \mathrm{e}-08)$ & $(1.50 \mathrm{e}-08)$ & $(1.44 \mathrm{e}-08)$ & $(1.44 \mathrm{e}-08)$ \\
\hline \multirow[t]{5}{*}{ Controls } & Year, type, region & Yes & Yes & Yes & Yes \\
\hline & Constant & $-0.0183^{* *}$ & $-0.0195 * *$ & $-0.0187 * *$ & $-0.0193 * *$ \\
\hline & & $(0.00783)$ & $(0.00825)$ & $(0.00761)$ & $(0.00773)$ \\
\hline & Observations & 332 & 332 & 332 & 332 \\
\hline & R-squared & 0.209 & 0.221 & 0.209 & 0.215 \\
\hline
\end{tabular}

Cluster robust standard errors in parentheses

Dependent variable: DAit Discretionary accruals

${ }^{\dagger}$ Explanatory note: If the additional accruals management for a pre-managed component rating of 2 is driven by intervention avoidance then we would not expect to see significance on the coefficient ( $\alpha_{2}$ in equation 3 ) on Comp when the pre-managed component rating is just above 3 (as there would be no threat of intervention in this case) or when the component rating is just below 2 (as additional accruals management is unlikely to take the Trust out of intervention measures). 


\section{Figures}

Figure 1

The component metrics of the financial risk rating for Foundation Trusts

\begin{tabular}{|c|c|c|c|c|c|c|c|}
\hline \multirow[t]{2}{*}{ Measure } & \multirow[t]{2}{*}{ Metric to be scored } & \multirow[t]{2}{*}{ Weight $\%$} & \multicolumn{5}{|c|}{ Risk Rating } \\
\hline & & & 1 & 2 & 3 & 4 & 5 \\
\hline \multirow{2}{*}{$\begin{array}{l}\text { Financial } \\
\text { efficiency }\end{array}$} & I\&E surplus margin $\%$ & 20 & $<-2$ & -2 & 1 & 2 & 3 \\
\hline & Return on assets excluding dividend ${ }^{1} \%$ & 20 & $<-2$ & -2 & 3 & 5 & 6 \\
\hline $\begin{array}{l}\text { Underlying } \\
\text { performance }\end{array}$ & EBITDA margin \% & 25 & $<1$ & 1 & 5 & 9 & 11 \\
\hline Liquidity & Liquidity ratio (days) $^{2}$ & 25 & $<10$ & 10 & 15 & 25 & 60 \\
\hline $\begin{array}{l}\text { Achievement of } \\
\text { plan }\end{array}$ & EBITDA\% of plan & 10 & $<50$ & 50 & 70 & 85 & 100 \\
\hline
\end{tabular}

(Source: (Adapted from) Monitor, 2009b. p.14.)

All terms and definitions are taken from the regulator's compliance framework.

${ }^{1}$ This is broadly equivalent to a return on capital measure. It is calculated as the income and expenditure surplus (after deduction of finance costs but before the dividend on public dividend capital) divided by taxpayers' equity plus debt (including Private Finance Initiative balances and finance leases). The public dividend is a fixed charge of $3.5 \%$ on taxpayers' equity and thus essentially resembles a cost of capital charge rather more than a dividend.

2 The liquidity ratio is defined as cash plus trade debtors (including accrued income) minus (trade creditors plus accruals) plus unused committed or available working capital facility expressed as a number of days of operating expenses (excluding depreciation). Note: this ratio is referred to as a 'liquidity' ratio by the regulator but has features consistent with a cash conversion cycle.

(Note the commercialization of the terminology applied to Foundation Trusts in the reference to EBITDA even though Foundation Trusts do not generate 'earnings' as such).

The final 'financial risk rating' is the weighted average of the metric scores as illustrated below:

\section{Derivation of a Foundation Trust 'financial risk rating': An illustration}

Example: Trust X has an I\&E surplus margin of $0.8 \%$, an ROA of 3.5\% EBITDA margin of 6.2\%, liquidity of 28 days of operating expenses, and achievement of plan of $83 \%$.

\begin{tabular}{|l|c|c|c|c|}
\hline Metric & $\begin{array}{c}\text { Actual } \\
\text { performance }\end{array}$ & $\begin{array}{c}\text { Component risk } \\
\text { rating }\end{array}$ & Weighting & $\begin{array}{c}\text { Weighted } \\
\text { component } \\
\text { risk rating }\end{array}$ \\
\hline \hline I\&E surplus margin & $0.8 \%$ & 2 & $20 \%$ & 0.40 \\
\hline Return on assets & $3.5 \%$ & 3 & $20 \%$ & 0.60 \\
\hline EBITDA margin & $6.2 \%$ & 3 & $25 \%$ & 0.75 \\
\hline Liquidity & 28 days & 4 & $25 \%$ & 1.00 \\
\hline Achievement of plan \% & $83 \%$ & 3 & $10 \%$ & 0.30 \\
\hline \multicolumn{5}{|r|}{ FINAL RISK RATING } \\
\hline
\end{tabular}


Figure 2

Prudential borrowing limit - the determining ratios

\begin{tabular}{|l|c|}
\hline Ratio & $\begin{array}{l}\text { Required level of } \\
\text { performance }\end{array}$ \\
\hline Dividend cover & $>1$ \\
\hline Interest cover & $>3$ \\
\hline Debt service cover & 2 \\
\hline Debt service to revenue & $<2.5 \%$ \\
\hline
\end{tabular}

Definitions:

Dividend cover: (Revenue Available for Debt Service minus Annual Interest) divided by Annual PDC Dividend Interest cover: Revenue Available for Debt Service divided by Annual Interest

Debt service cover: Revenue Available for Debt Service divided by Annual Debt Service

Debt service to revenue: Annual Debt Service divided by Revenue 
Figure 3

Risk rating metrics - definitions

(sourced from the Regulator's compliance framework documents ${ }^{21}$ )

\begin{tabular}{|c|c|c|c|c|}
\hline \multirow{2}{*}{$\begin{array}{l}\text { Financial } \\
\text { Criteria }\end{array}$} & \multirow{2}{*}{$\begin{array}{l}\text { Compliance } \\
\text { Framework } \\
\text { Definition }\end{array}$} & \multicolumn{3}{|c|}{ Actual Calculation for years: } \\
\hline & & $\begin{array}{l}2009 / 10 \text { and } \\
2010 / 11\end{array}$ & 2011/12 & $\begin{array}{l}2012 / 13 \text { and } \\
2013 / 14\end{array}$ \\
\hline \multirow[t]{2}{*}{$\begin{array}{l}\text { Financial } \\
\text { efficiency }\end{array}$} & $\begin{array}{l}\text { Return on Assets } \\
\text { excluding } \\
\text { dividend }(\%) \text { or } \\
\text { Net Return after } \\
\text { Financing }(\%)\end{array}$ & $\begin{array}{l}\text { (Adjusted I\&E } \\
\text { Surplus/(Deficit) }^{2} \\
\text { + PDC Dividend } \\
\text { Expense) divided } \\
\text { by Total Assets } \\
\text { Employed }^{3}\end{array}$ & $\begin{array}{l}\text { EBIT }^{5} \text { divided by } \\
\text { Capital } \\
\text { Employed }\end{array}$ & $\begin{array}{l}\text { Earnings after } \\
\text { Financing } \\
{ }^{7} \\
\text { divided by Capital } \\
\text { Employed }^{8}\end{array}$ \\
\hline & $\begin{array}{l}\text { I\&E Surplus } \\
\text { Margin net of } \\
\text { Dividend }(\%)\end{array}$ & $\begin{array}{l}\text { Adjusted I\&E } \\
\text { Surplus/(Deficit) } \\
\text { divided by } \\
\text { Operating } \\
\text { Income/Revenue }\end{array}$ & $\begin{array}{l}\text { Same as previous } \\
\text { periods }\end{array}$ & $\begin{array}{l}\text { Same as previous } \\
\text { periods }\end{array}$ \\
\hline $\begin{array}{l}\text { Underlying } \\
\text { performance }\end{array}$ & $\begin{array}{l}\text { EBITDA margin } \\
(\%)\end{array}$ & $\begin{array}{l}\text { EBITDA divided } \\
\text { by Operating } \\
\text { Income/Revenue }\end{array}$ & $\begin{array}{l}\text { Same as previous } \\
\text { periods }\end{array}$ & $\begin{array}{l}\text { Same as previous } \\
\text { periods }\end{array}$ \\
\hline $\begin{array}{l}\text { Achievement of } \\
\text { plan }\end{array}$ & $\begin{array}{l}\text { EBITDA } \\
\text { achieved ( } \% \text { of } \\
\text { plan) }\end{array}$ & $\begin{array}{l}\text { Actual EBITDA }{ }^{1} \\
\text { margin divided by } \\
\text { planned EBITDA } \\
\text { margin }\end{array}$ & $\begin{array}{l}\text { Same as previous } \\
\text { periods }\end{array}$ & $\begin{array}{l}\text { Same as previous } \\
\text { periods }\end{array}$ \\
\hline Liquidity & $\begin{array}{l}\text { 'Liquidity ratio' } \\
\text { [expressed as a } \\
\text { cash conversioin } \\
\text { cycle] (days) }\end{array}$ & $\begin{array}{l}\text { Net Liquid } \\
\text { Resources } \\
\text { divided by } \\
\text { Operating } \\
\text { Expenses } * 365\end{array}$ & $\begin{array}{l}\text { Same as previous } \\
\text { periods }\end{array}$ & $\begin{array}{l}\text { Same as previous } \\
\text { periods }\end{array}$ \\
\hline
\end{tabular}

Notes:

${ }^{1}$ EBITDA is defined as: Total Operating Income - Total Operating Expenses (excl. Finance Costs, Depreciation, Amortisation and Exceptional Items).

${ }^{2}$ Adjusted I\&E Surplus/(Deficit) is defined as: Net I\&E Surplus/(Deficit) after Tax add back Exceptional Income/Costs \& Impairments.

${ }^{3}$ Total Assets Employed is defined as: Period Average of (Net Assets + Borrowings).

${ }^{4}$ Net Liquid Resources is defined as: Current Assets (excl. Inventories, Derivative Related Assets, Available/Held for Sale Assets and Charitable Funds Assets) - Current Liabilities (excl. Charitable Funds Liabilities) + any unused Committed ${ }^{10}$ Working Capital Facilities.

${ }^{5}$ EBIT is defined as: EBITDA, as noted above, less Depreciation \& Amortisation.

${ }^{6}$ Capital Employed is defined as: Period Average of (Total Assets - Current Liabilities).

${ }^{7}$ Earnings after Financing is defined as: EBITDA - Tax - Net Finance Expense (incl. PDC dividend, PFI ${ }^{11}$ financing and other financial lease costs).

${ }^{8}$ Capital Employed is defined as: Period Average of (Taxpayers' Equity + Lease Liabilities + Borrowing).

${ }^{9}$ PDC: Public Dividend Capital represents the Department of Health's long term investment in each Trust that, although repayable, does not have a defined repayable schedule. It was initially provided to NHS Trusts when they were first formed to enable them to purchase the Trust's assets from the Secretary of State. It appears in the Trust's 'taxpayer's equity' section of their Statement of Financial Position and is similar in status to share capital in a company. The PDC dividend however is not a charge related to the value of Public Dividend Capital (PDC) alone. It is paid at a rater of 3.5\% of the average net relevant assets of a trust. Net relevant assets are broadly equivalent to Taxpayers equity but after the deduction of some specific reserves such as the donated asset reserve. (NHS Trust Development Authority 2016, Annex 7, Appendix 6)

${ }^{10}$ Committed working capital: Foundation Trusts are required by the regulator to have working capital facilities in place with banks of about one month's operational expenditure.

${ }^{11}$ PFI - Private finance initiative: a method of providing funds for major capital investments where private firms provide the capital investment for public projects, such as new hospital facilities, and then lease the project assets back to the relevant public body - in this case an NHS Foundation Trust.

${ }^{12}$ Taxpayers' Equity: Public dividend capital plus reserves (e.g. the income and expenditure reserve)

${ }^{21}$ Monitor, 2009b, p. 14, 2011 p. 23, 2013, p. 23. 
Page $\mid 45$ 
Figure 4

\section{Predicted signs of coefficients on independent variables}

\begin{tabular}{|c|c|c|c|c|c|}
\hline $\begin{array}{l}\text { Independent } \\
\text { variable }\end{array}$ & \multicolumn{2}{|l|}{ Description } & Hypothesis & & $\begin{array}{l}\text { Expected } \\
\text { sign }\end{array}$ \\
\hline Pre-mSurp & \multicolumn{2}{|l|}{$\begin{array}{l}\text { Pre-managed } \\
\text { surplus }\end{array}$} & $H 1$ & $\begin{array}{l}\text { Discretionary accruals will be } \\
\text { managed to report small surpluses }\end{array}$ & -ve \\
\hline \multirow[t]{4}{*}{ Rating } & \multirow{4}{*}{$\begin{array}{l}\text { Pre-managed } \\
\text { 'financial risk } \\
\text { rating' }\end{array}$} & 1 & $H 2 b$ & No additional accruals management & \\
\hline & & 2 & $H 2 a$ & $\begin{array}{l}\text { Discretionary accruals will be } \\
\text { additionally income increasing in } \\
\text { order to avoid regulatory intervention }\end{array}$ & $+\mathrm{ve}$ \\
\hline & & 3 & $H 2 b$ & No additional accruals management & \\
\hline & & $\begin{array}{l}4 \text { or } \\
5\end{array}$ & $H 2 b$ & No additional accruals management & \\
\hline \multirow[t]{2}{*}{ Comp } & \multicolumn{2}{|c|}{$\begin{array}{l}=1 \text { for breach of the } \\
\text { pre-managed } \\
\text { prudential } \\
\text { borrowing limit }\end{array}$} & $H 2 a$ & $\begin{array}{l}\text { Discretionary accruals will be } \\
\text { additionally income increasing in } \\
\text { order to avoid regulatory intervention }\end{array}$ & $+\mathrm{ve}$ \\
\hline & \multicolumn{2}{|c|}{$\begin{array}{l}=1 \text { for small pre- } \\
\text { managed deficit }\end{array}$} & $H 2 c$ & $\begin{array}{l}\text { Discretionary accruals will be } \\
\text { additionally income increasing }\end{array}$ & $+\mathrm{ve}$ \\
\hline
\end{tabular}

Dependent variable $=$ discretionary accruals.

The derivation of aTrust's financial risk rating can be found in Figure 1.

A risk rating of 2 triggers regulatory intervention in the form of additional reporting requirements but can escalate for a risk rating of 1 to more direct intervention and ultimately to removal of the Board and Governing Body.

A risk rating of 3 is the default level of regulatory monitoring which involves the submission of quarterly financial returns.

A risk rating of 4 or 5 generates rewards in the form of a lower frequency of reporting (bi-annually) and access to additional resources. 